\title{
NEKOLIKO PITANJA U VEZI S PRIMJENOM MEĐUNARODNIH UGOVORA U MEĐUNARODNOM PRIVATNOM PRAVU REPUBLIKE SRBIJE***
}

Sažetak: $\quad$ U radu se razmatraju značajna praktična pitanja koja se javljaju pri primjeni međunarodnih ugovora u području međunarodnog privatnog prava. Pri tome, posebno se imaju u vidu složene situacije koje mogu nastati u vezi sa stupanjem ugovora na snagu u međunarodnom i u unutrašnjem smislu, sukcesijom međunarodnih ugovora, kao i glede međusobnog odnosa samih međunarodnih ugovora. Takoder, razmatra se i potreba revidiranja postojećih dvostranih ugovora, s obzirom na rješenja pojedinih konvencija Haške konferencije za međunarodno privatno pravo čije se polje primjene (djelomično) poklapa s poljem primjene ranije zaključenih dvostranih ugovora. Uz to, u radu se ukazuje i na slučajeve kada su inovirana rješenja ZMPP-a Republike Hrvatske i Nacrta ZMPP-a Republike Srbije znatno povoljnija u odnosu na obvezujući višestrani ugovor o utvrđivanju sadržaja stranog prava.

Ključne riječi: $\quad$ stupanje na snagu međunarodnog ugovora, primjena međunarodnog ugovora, hijerarhija medunarodnih ugovora, ratifikacija međunarodnih ugovora, Europska konvencija o obavijestima o stranom pravu

\footnotetext{
* Dr. sc. Mirko Živković, redovni profesor, Pravni fakultet Univerziteta u Nišu, Trg kralja Aleksandra 11, 18105 Niš, Republika Srbija. Adresa e-pošte: mirko.zivkovic@yahoo.fr. ORCID: https://orcid.org/0000-0002-5624-9804.

** Dr. sc. Sanja Marjanović, docentica, Pravni fakultet Univerziteta u Nišu, Trg kralja Aleksandra 11, 18105 Niš, Republika Srbija. Adresa e-pošte: sanjamarjan@yahoo.com. ORCID: https://orcid.org/ 0000-0001-7560-8254.

*** Ovaj rad je rezultat angažiranosti na projektu Pravnog fakulteta Univerziteta u Nišu "Zaštita ljudskih i manjinskih prava u evropskom pravnom prostoru", koji financira Ministarstvo prosvete, nauke i tehnološkog razvoja Republike Srbije (evidencijski broj 179046 D).
} 


\section{UVOD}

Pri primjeni međunarodnih ugovora koji uređuju područje međunarodnog privatnog prava, mogu se pojaviti određene nedoumice i teškoće praktične prirode. One se vezuju za dužnost poznavanja međunarodnih ugovora, njihovo pronalaženje, redoslijed u primjeni (kako u odnosu na unutrašnje izvore, tako i glede njihova međusobnog odnosa), kao i na njihovo stupanje na snagu. Uz to, pojedini ugovori pokazuju očite znakove starenja i tako anakronični bivaju predmet zahtjeva za revizijom od strane EU-a ili samih država ugovornica. Napokon, pojedini višestrani međunarodni ugovori sadrže rješenja koja nas, unatoč svom nominalnom primatu, dovode u zabunu pri susretu s pojedinim zakonskim rješenjima. O tim pitanjima bit će riječi u ovom članku.

\section{DUŽNOST POZNAVANJA MEĐUNARODNIH UGOVORA}

U pravnom rječniku koriste se različiti nazivi za označavanje akata koji imaju status međunarodnih ugovora - ugovor, sporazum, konvencija, pakt, povelja, protokol. Ove razlike u nazivima, kako je poznato, ne označavaju i neku razliku sadržajne prirode. Bez obzira na naziv, svi ovi akti, ako ispunjavaju uvjete predviđene Bečkom konvencijom o ugovornom pravu (1969), ${ }^{1}$ smatraju se međunarodnim ugovorima. Naime, prema članku 2. ove Konvencije, međunarodni ugovor je svaki sporazum između država zaključen u pisanu obliku i reguliran međunarodnim pravom, bez obzira na naziv i bez obzira na to sastoji li se od jednog ili više akata koji su međusobno povezani. Sličnu odredbu sadrži i stavak 1. članka 2. Zakona o zaključivanju i izvršavanju međunarodnih ugovora Republike Srbije (2013). ${ }^{2}$ Prema tome, naziv "međunarodni ugovor" je zajednički naziv za sve ove akte, a njegovo konkretno ime proizilazi iz neke specifičnosti koja, pravno promatrano, nije od presudna značenja (recimo, iz prakse određene međunarodne organizacije, situacije u kojoj je donesen, područja koje uređuje i sl.).

Međunarodni ugovori koji su potvrđeni i objavljeni u skladu s Ustavom sastavni su dio unutrašnjeg pravnog poretka. ${ }^{3}$ To znači da se oni smatraju dijelom unutrašnjeg prava i da za njih vrijedi pretpostavka iura novit curia, odnosno da sud poznaje pravo - kao što zna za postojanje pojedinih zakona i poznaje njihove odredbe, sudac mora znati i za postojanje određenih međunarodnih ugovora i poznavati njihove odredbe. ${ }^{4}$ Dakle, sud ili drugo tijelo primjene prava ne može se izgovarati da mu nisu poznate pravne norme sadržane u ugovoru - on je dužan

1 Članak 2. st. 1. t. a) Bečke konvencije o ugovornom pravu, Službeni list SFRJ, Međunarodni ugovori i drugi sporazumi, broj 30/1972.

2 Zakon o zaključivanju i izvršavanju međunarodnih ugovora, Službeni glasnik RS, broj 32/2013.

3 Članak 16. st. 2. Ustava Republike Srbije, Službeni glasnik RS, broj 98/2006.

4 Ova maksima, prema pojedinim autorima, vrijedi bez izuzetka i u kad je posrijedi strano merodavno pravo. Vidjeti Varadi, T.; Bordaš, B.; Knežević, G.; Pavić, V., Međunarodno privatno pravo, Službeni glasnik, Beograd, 2016., str. 114. Međutim, u dijelu domaće doktrine međunarodnog privatnog prava, smatra se da je pravo iura novit curia relativizirano u slučaju kada je prema kolizijskoj normi mjerodavno strano pravo te je sudu ili drugom nadležnom tijelu potrebna pomoć u utvrđivanju sadržaja stranog prava. Vidjeti detaljnije Stanivuković, M.; Živković, M., Međunarodno privatno pravo: opšti deo, Službeni glasnik, Beograd, 2015., str. 304.-305. 
znati za postojanje međunarodnih ugovora koji su na snazi u našoj zemlji, poznavati njihov sadržaj i primjenjivati njihove odredbe ako su ispunjeni odgovarajući uvjeti. ${ }^{5}$

\subsection{PRAVILO “NAJPRIJE PROVJERITI”}

Svaki pravnik koji rješava određeno pravno pitanje iz područja međunarodnog privatnog prava, prije nego što konzultira zakonske odredbe, mora najprije provjeriti (jer, u pravilu, ne zna unaprijed!) postoji li između Republike Srbije i involvirane strane države dvostrani ugovor ili su obje članice višestranog ugovora u području na koju se pravno pitanje odnosi. ${ }^{6}$ Smatrajući da je pitanje hijerarhije međunarodnih i unutrašnjih izvora osnovno pravilo od čijeg pravilnog rješenja ovisi i pravilno utvrđivanje normi međunarodnog privatnog prava koje treba primijeniti u svakom konkretnom slučaju, u ovom radu je nazvano pravilom "najprije provjeriti". Ono proizilazi iz ustavnih i zakonskih odredaba o redoslijedu primjene normi međunarodnog privatnog prava (hijerarhija izvora). Zanemarimo li ga, može nam se dogoditi da spor rješavamo prema normama međunarodnog privatnog prava sadržanim u zakonima, koje su različite od onih sadržanih u međunarodnim ugovorima. Na taj način, riskirali bismo pogrešku u konačnici. Na primjer, ako je riječ o priznanju odluke o uzdržavanju iz Izraela, moramo najprije provjeriti postoji li dvostrani ili višestrani ugovor koji uređuje to pitanje u odnosima Srbije i Izraela. Tek kada utvrdimo da nema dvostranog, odnosno višestranog ugovora u ovoj pravnoj stvari (a u ovom slučaju - nema!), mogli bismo primijeniti odgovarajuće zakonske odredbe. Međutim, drukčije bi bilo kada bi bila riječ o odluci iz Belgije (ili Austrije) $^{8}$ jer bismo nakon provjere utvrdili da postoji dvostrani međunarodni ugovor koji ovo pitanje regulira i čije bi norme u tom slučaju trebalo primijeniti.

\subsection{PRONALAŽENJE MEĐUNARODNIH UGOVORA}

Dužnost poznavanja međunarodnih ugovora i pravilo "najprije provjeriti" vode nas do problema koji je donedavno stvarao velike teškoće u praksi. Riječ je o pronalaženju međunarodnog ugovora, odnosno o pitanju kako će pravnik praktičar uopće znati za postojanje međunarodnog ugovora, posebno kada je riječ o starijim međunarodnim ugovorima, zaključenim prije dva, tri ili više desetljeća.

Pronalaženje takvog međunarodnog ugovora doskora nije bio jednostavan niti lak zadatak. Budući da je Srbija pravna nasljednica Državne zajednice Srbija i Crna Gora, kao i ranije

5 Vidjeti infra ad 3. i 4.

6 O univerzalnom problemu tzv. "zaboravljenih ugovora”, vidjeti von Overbeck, A. E., L'application par le juge interne des conventions de droit international privé, Collected Courses of the Hague Academy of International Law, Hague Academy of International Law, The Hague, Vol. 132, 1971, pp. 14-15.

7 Konvencija između Socijalističke Federativne Republike Jugoslavije i Kraljevine Belgije o priznanju i izvršenju odluka o izdržavanju, Službeni list SFRJ, Međunarodni ugovori i drugi sporazumi, broj 45/1976.

8 Sporazum između Jugoslavije i Austrije o uzajamnom priznavanju i izvršenju odluka o izdržavanju, Službeni list SFRJ - Dodatak, broj 2/1963. 
Jugoslavije (SRJ, SFRJ i FNRJ), ugovor za kojim se traga može se nalaziti u nekoj od starijih službenih publikacija u kojima su objavljivani međunarodni ugovori. Pregledati sve dodatke Službenog lista šezdeset godina unatrag, pritom još voditi računa o ugovorima koje je zaključila Kraljevina Jugoslavija ili još prije Kraljevina Srba, Hrvata i Slovenaca, odnosno Kraljevina Srbija, a koji su nakon Drugog svjetskog rata preuzeti u Jugoslaviji, zaista je golem posao koji nadilazi mogućnosti jednog pravnika praktičara.

Međutim, danas je zadatak znatno olakšan pojavom elektronskih baza podataka (na primjer, Paragraf Lex). ${ }^{9}$ Osim toga, ti ugovori nalaze se i na mrežnim stranicama Ministarstva pravde ${ }^{10}$ i Ministarstva spoljnih poslova Srbije. ${ }^{11}$ U pravilu, dvostrani ugovori su sistematizirani prema državama ugovornicama (te treba provjeriti postoji li s određenom državom ugovor o pravnoj stvari na koju se odnosi konkretno pravno pitanje), a kod višestranih, jesu li Republika Srbija i konkretna strana država članice odgovarajućeg ugovora koji regulira to pravno pitanje.

Ako mu ovi tekstovi u elektronskom obliku nisu dostupni, pravnik se može poslužiti objavljenim zbirkama međunarodnih ugovora iz pojedinih područja, koje mogu biti korisne, iako su u njima obično dani samo prijevodi međunarodnih ugovora na srpski jezik, bez vjerodostojnog teksta. ${ }^{12}$ Osim toga, upotrebljavajući ove zbirke treba biti oprezan jer one tijekom vremena zastarijevaju - nakon objavljivanja, zaključuju se novi ugovori, a neki od navedenih, zbog toga ili zbog drugih razloga, prestaju vrijediti. Također, moguće je da ti ugovori na srpskom jeziku sadrže i određene pogreške u prijevodu (npr. često nalazimo da se "habitual residence", "residence habituelle" (uobičajeno boravište) prevodi kao "stalno nastanjenje”, što više podsjeća na prebivalište ${ }^{13}$ ili da se "public policy" (“javni poredak”), koji predstavlja specifičnu ustanovu međunarodnog privatnog prava, prevodi kao "pravni poredak", odnosno "javni red". ${ }^{14}$

\section{PRIMJENA MEĐUNARODNIH UGOVORA}

Uz dužnosti poznavanja međunarodnih ugovora, sudovi i druga tijela imaju i dužnost njihove primjene, ako su ispunjeni potrebni uvjeti. Riječ je o sljedećim uvjetima:

a) da konkretno pravno pitanje pripada u područje primjene danog međunarodnog ugovora

9 Paragraf Lex je elektronska pravna baza koja sadrži bazu propisa, sudske prakse i mnoge druge korisne informacije o važećem pravu. Uz Srbiju, dostupan je i u Bosni i Hercegovini i Crnoj Gori. Vidjeti URL= https://www.paragraf.rs/. Pristupljeno 25. veljače 2019.

10 Ministarstvo pravde Republike Srbije, Bilateralni i multilateralni međunarodni ugovori u građanskim stvarima. URL=https:// www.mpravde.gov.rs/tekst/47/medjunarodni-ugovori-u-gradjanskim-stvarima.php. Pristupljeno 25. veljače 2019.

11 Ministarstvo spoljnih poslova Republike Srbije, Bilateralni odnosi sa stranim državama. URL=http://www.mfa.gov.rs/sr/index.php/spoljna-politika/bilateralni-odnosi?lang=cyr. Pristupljeno 25. veljače 2019.

12 Todorović, V., Međunarodna pravna pomoć: 78 multilateralnih međunarodnih konvencija, Službeni glasnik, Beograd, 2003. Todorović, V., Međunarodna pravna pomoć: bilateralne konvencije, Službeni glasnik, Beograd, 1999. Pravosudne bilateralne konvencije, Projuris, Beograd, 2005. Pravosudne multilateralne konvencije, Projuris, Beograd, 2005. Todorović. V., Pravosudna međunarodna pomoć, Projuris, Beograd, 2005.

13 Članak 3. st. 1 Zakona o ratifikaciji Konvencije o građanskopravnim aspektima međunarodne otmice dece, Službeni list SFRJ, Međunarodni ugovori, broj 7/1991.

14 Primjerice čl. 10. st. 1. Uredbe o ratifikaciji Konvencije o zakonu koji se primjenjuje na prometne nezgode, Službeni list SFRJ, Međunarodni ugovori i drugi sporazumi, broj 26/1976. 
b) da je međunarodni ugovor stupio na snagu.

\subsection{ODREĐIVANJE PODRUČJA PRIMJENE MEĐUNARODNOG UGOVORA}

Sudac ili drugo tijelo mora pozorno utvrditi područje primjene međunarodnog ugovora. Na taj način, ustanovit će mogu li se na konkretno pravno pitanje primijeniti odredbe ugovora, odnosno vice versa, pripada li ono u područje primjene međunarodnog ugovora.

Područje primjene međunarodnog ugovora može biti određeno na različite načine - izričitim nabrajanjem pravnih stvari na koju se ugovor odnosi ili nabrajanjem pitanja na koje se njegove odredbe ne primjenjuju. Kad je posrijedi širina kruga država na koje se primjenjuje, ugovor može predviđati uvjet uzajamnosti ( $\mathrm{tj}$. primjenjivati se samo u odnosima država ugovornica) ili biti univerzalnog karaktera (primjenjivati se i u odnosima s državama nečlanicama). Uz to, njegova primjena može biti ograničena ili uvjetovana i klauzulom teritorijalnog karaktera, zatim, odrednicom o vremenskom važenju ugovora, kao i pojedinim rezervama koje je stavila, odnosno izjavama koje je dala neka država članica. Razmotrimo bliže spomenute modalitete u primjeni ugovora.

Najprije, područje primjene ugovora određuje se često nabrajanjem u samom tekstu ugovora vrste pravnih odnosa ili pravnih pitanja na koja se ugovor odnosi. Također, čest je slučaj da se u ugovoru, $\mathrm{u}$ istom cilju - preciznijem određivanju područja primjene i izbjegavanja problema kvalifikacije (tumačenja) pojedinih pojmova - uz nabrajanje pravnih stvari koje ulazi u područje primjene ugovora, navode i odnosi i pitanja koja se izričito isključuju iz njegova područja primjene. ${ }^{15}$ Napokon, uz nabrajanje, katkad se (u sljedećem članku) izričito definiraju pojedini pojmovi ili izrazi (tzv. autonomni pojmovi) kako bi se izbjeglo njihovo tumačenje prema nacionalnim pravima država članica i omogućila ujednačena primjena međunarodnog ugovora. ${ }^{16}$

Uvjet uzajamnosti znači da se ugovor primjenjuje samo u odnosima između država ugovornica, pri čemu dodatni kriterij primjene može, ali ne mora biti određen. Ako je ipak određen, to se može učiniti na različite načine. Primjera radi, Haška konvencija o građanskom postupku $(1954)^{17}$ predviđa da su od obveze polaganja aktorske kaucije izuzeti državljani država ugovornica koji imaju prebivalište (dodatni uvjet) u bilo kojoj državi ugovornici; za razliku od toga, prema Haškoj konvenciji o olakšanju međunarodnog pristupa sudovima (1980), ${ }^{18}$ kategorija osoba oslobođenih ove obveze nešto je drukčija - ona obuhvaća osobe koje imaju uobičajeno

15 Primjerice čl. 2. Konvencije o zakonu koji se primjenjuje na prometne nezgode. Članci 3. i 4. Konvencije o nadležnosti, merodavnom pravu, priznanju i izvršenju odluka i saradnji u materiji roditeljske odgovornosti i mera za zaštitu dece, Službeni glasnik RS, Međunarodni ugovori, broj 20/2015. Članak 1. st. 2. i 3. Konvencije o ukidanju potrebe legalizacije stranih javnih isprava, Službeni list FNRJ, Međunarodni ugovori i drugi sporazumi, broj 10/1962.

von Overbeck, A. E., op.cit., p. 61. Primjerice članak 1. st. 2. Konvencije o nadležnosti, merodavnom pravu, priznanju i izvršenju odluka i saradnji u materiji roditeljske odgovornosti i mera za zaštitu dece, Službeni glasnik RS, Međunarodni ugovori, broj 20/2015. Članak 1. st. 2. Konvencije o ukidanju potrebe legalizacije stranih javnih isprava, Službeni list FNRJ, Međunarodni ugovori i drugi sporazumi, broj 10/1962. Članak 2. Konvencije o zakonu koji se primjenjuje u slučajevima odgovornosti proizvođača za svoje proizvode, Službeni list SFRJ, Međunarodni ugovori, broj 8/1977. 
boravište (dodatni uvjet) u bilo kojoj državi ugovornici, bez obzira na to jesu li državljani države ugovornice ili neke treće države.

Neki ugovori formuliraju uvjet reciprociteta tako što se primjenjuju samo na državljane država ugovornica bez dodatnih uvjeta. Međutim, može biti riječ o aktima izdanima na području jedne države ugovornice, a koji trebaju biti upotrijebljeni na području druge države ugovornice, bez obzira na državljanstvo osoba o kojima je riječ - recimo, isprave izdane na području jedne države ugovornice koje trebaju biti upotrijebljene na području druge države ugovornice (članak 1. stavak 1. Haške konvencija o ukidanju zahtjeva legalizacije stranih javnih isprava (1961). ${ }^{19}$ Također, može biti riječ i o postojanju poslovnog sjedišta strana ugovornica na područjima država ugovornica (Konvencija o zastarjelosti potraživanja u području međunarodne kupoprodaje robe $)^{20}$ i sl.

Upravo zbog toga, obje vrste ovih ugovora u doktrini se označavaju kao ugovori koji se primjenjuju pod uvjetom reciprociteta.

Nasuprot tome, određene konvencije primjenjuju se bez uvjeta reciprociteta. Tako, pojedine haške konvencije koje se odnose na određivanje mjerodavnog prava (primjerice, haški Protokol o mjerodavnom pravu za obveze uzdržavanja $(2007)^{21}$ u članku 2. predviđa da će se pravo na koje ukazuju njegove odredbe primijeniti $i$ kada ono ne pripada državi članici Protokola). Na taj način, norma koja ima porijeklo u međunarodnom ugovoru dobiva karakter norme općeg prava države ugovornice - primjenjuje se u odnosima i s državama članicama i s državama nečlanicama tog ugovora, dakle svaki put kada sudac treba odrediti mjerodavno pravo za uzdržavanje. Treba primijetiti da takve kolizijske norme (tzv. univerzalne kolizijske norme) sadrže i druge haške konvencije, kao i pojedine uredbe Europske unije. ${ }^{22}$

Osim navedenih načina, područje primjene jednog ugovora može sadržavati i vremensku odrednicu (na primjer, da se primjenjuje na određenu vrstu odnosa nastalih nakon njegova stupanja na snagu). Tako, stavak 1. članka 35. haške Konvencije o građanskopravnim aspektima međunarodne otmice djece $(1980)^{23}$ predviđa da se “(...) ova Konvencija primjenjuje među državama ugovornicama samo u odnosu na nezakonita odvođenja ili zadržavanja do kojih je došlo nakon njenog stupanja na snagu u tim državama". Također, područje primjene ugovora

Službeni list FNRJ, Međunarodni ugovori i drugi sporazumi, broj 10/1962.

20 Službeni list SFRJ, Međunarodni ugovori, broj 5/1978.

21 Službeni glasnik RS, Međunarodni ugovori, broj 1/2013.

Na primjer, takve kolizijske norme sadrže čiji članak 15. upućujući na primjenu Haškog protokola o mjerodavnom pravu za obveze izdržavanja; čl. 20. Uredbe EU-a o nadležnosti, mjerodavnom pravu, priznanju i izvršenju odluka i prihvaćanju i izvršenju autentičnih instrumenata u materiji nasljeđivanja i stvaranja Europskog certifikata o nasljeđivanju (Regulation (EU) No 650/2012 of the European Parliament and of the Council of 4 July 2012 on jurisdiction, applicable law, recognition and enforcement of decisions and acceptance and enforcement of authentic instruments in matters of succession and on the creation of a European Certificate of Succession, OJ L 201, 27. 7. 2012); čl. 4. Uredbe EU-a o pojačanoj suradnji u području mjerodavnog prava za razvod braka i rastavu (Council Regulation (EU) No 1259/2010 of 20 December 2010 implementing enhanced cooperation in the area of the law applicable to divorce and legal separation, OJ L 343, 29. 12. 2010); čl. 6. st. 2. Haške konvencije o sukobu zakona u vezi s oblicima testamentarnih odredaba (Službeni list FNRJ, Međunarodni ugovori i drugi sporazumi, broj 10/1962); čl. 11. Haške konvencije o merodavnom pravu za drumske saobraćajne nezgode (Službeni list SFRJ, Međunarodni ugovori i drugi sporazumi, broj 26/1976); čl. 11. Haške konvencije o odgovornosti proizvođača za svoje proizvode (Službeni list SFRJ, Međunarodni ugovori, broj 8/1977); čl. 2. Haškog protokola o merodavnom pravu za obaveze izdržavanja (Službeni glasnik RS, Međunarodni ugovori, broj 1/2013); čl. 20. Haške konvencije o nadležnosti, merodavnom pravu, priznanju i izvršenju odluka i saradnji u materiji roditeljske odgovornosti i mera za zaštitu dece (Službeni glasnik RS, Međunarodni ugovori, broj 20/2015). 
može biti precizirano i teritorijalnom klauzulom (npr. federalna klauzula; klauzula o teritorijalnom proširenju primjene ugovora), recimo, da ugovor ne vrijedi na cjelokupnom teritoriju neke države, nego samo na nekim njezinim područjima (federalnim jedinicama) ili da se njegova primjena proširuje i na neka druga područja, (najčešće, pod samo formalnim suverenitetom države ugovornice). Napokon, na područje primjene ugovora mogu utjecati i pojedine rezerve. $\mathrm{U}$ tom slučaju, pri primjeni ugovora, potrebno je utvrditi status međunarodnog ugovora $\mathrm{u}$ odnosu na tu državu ugovornicu. Mutatis mutandis, to vrijedi i za izjave koje je dala država ugovornica.

\subsection{STUPANJE NA SNAGU MEĐUNARODNIH UGOVORA}

Drugi uvjet za primjenu međunarodnog ugovora njegovo je stupanje na snagu. ${ }^{24}$ Pod tim se podrazumijeva da je on stupio na snagu kako u međunarodnom smislu, tako i u unutrašnjem pravnom poretku.

\subsubsection{STUPANJE NA SNAGU U MEĐUNARODNOM SMISLU}

Kod stupanja ugovora na snagu u međunarodnom smislu, riječ je o određivanju dana od kojega međunarodni ugovor vrijedi između država ugovornica, odnosno dana otkada ih on obvezuje. ${ }^{25}$ Taj dan obično je određen u samom tekstu ugovora - na primjer, pošto ga formalno potvrdi (ratificira) određen broj država ${ }^{26}$ i kada posljednja od njih deponira ispravu o potvrđivanju (ratifikaciji) kod depozitara ugovora (na primjer, kod pojedinih haških konvencija o međunarodnom privatnom pravu, riječ je najčešće o tri prve države, katkad i dvije, ali kod nekih drugih ugovora to može biti i veći broj država, recimo 30). ${ }^{27}$ Ovom uvjetu, također često, pridodaje se i određeni rok za stupanje na snagu ugovora nakon deponiranja posljednje (potrebne) isprave o potvrđivanju (ratifikaciji). ${ }^{28}$ Ugovorom može biti predviđeno da stupa na snagu u međunarodnom smislu i kada ga potvrde sve države ugovornice i kada protekne određen rok (takav je slučaj, na primjer, sa Sporazumom o pitanjima sukcesije bivše SFRJ iz 2001. godine ${ }^{29}$ koji je predviđao ratifikaciju od strane svih država sukcesora i protek roka od trideset dana za stupanje na snagu). ${ }^{30}$ Ako trenutak stupanja na snagu nije određen u samom ugovoru, smatra

24 Prema članku 25. Bečke konvencije o ugovornom pravu, države se mogu suglasiti da se ugovor ili dio ugovora privremeno primjenjuje i prije njegova stupanja na snagu.

Članak 24. Bečke konvencije o ugovornom pravu.

Taj broj može biti različit u ovisnosti o samom ugovoru, odnosno o međunarodnoj organizaciji u čijem okrilju se ugovor donosi.

Na primjer, Konvencija UN-a o imunitetu države i njezinoj imovini (United Nations Convention on Jurisdictional Immunities of States and Their Property), 2004. http://legal.un.org/ilc/texts/instruments/english/ conventions/4-1-2004.pdf. Pristupljeno 12. listopada 2018. ugovori, broj $1 / 2013$.

29 Službeni list SRJ, Međunarodni ugovori, broj 6/2002. 
se da on stupa na snagu onda kada sve države potpisnice potvrde (ratificiraju) ugovor u skladu sa svojim ustavnim odredbama. ${ }^{31}$

\subsubsection{STUPANJE NA SNAGU U UNUTRAŠNJEM SMISLU}

Stupanje na snagu međunarodnog ugovora u unutrašnjem pravnom poretku odnosi se na određivanje dana od kojega ugovor trebaju primjenjivati domaći sudovi ili druga tijela primjene prava (početak primjene međunarodnog ugovora). ${ }^{32}$ Dakle, to je određivanje dana otkada on počinje vrijediti u odnosu na domaću državu. ${ }^{33}$ Osnovno je pravilo da ugovor može stupiti na snagu u unutrašnjem pravnom poretku samo ako je stupio na snagu u međunarodnom smislu. ${ }^{34}$ Iznimku predstavlja ustanova privremene primjene ugovora, tj. mogućnost primjene ugovora (ili dijela ugovora) i prije nego što on stupi na snagu u međunarodnom smislu. Riječ je o tome da države koje pregovaraju mogu predvidjeti u samom ugovoru ili se sporazumjeti na neki drugi način da se ugovor ili dio ugovora privremeno primjenjuje i prije nego što stupi na snagu. ${ }^{35}$ Ove odredbe u pravu Republike Srbije pobliže su razrađene u Zakonu o zaključivanju i izvršavanju međunarodnih ugovora (čl. 8.).

S obzirom na to da se rokovi i uvjeti stupanja na snagu ugovora u međunarodnom smislu (sadržani u samom ugovoru) veoma često razlikuju od rokova stupanja na snagu koje pri objavljivanju ugovora u službenom glasilu države propisuje nacionalni zakonodavac, moguće je da zbog ove neusklađenosti nastanu određene nedoumice u vezi s početkom primjene ugovora od strane domaćih tijela. Pritom je potrebno razlikovati dvije situacije: prvu, kada Republika Srbija pristupa međunarodnom ugovoru koji je već na snazi u međunarodnom smislu, i drugu, kada pristupa ugovoru koji nije na snazi u međunarodnom smislu.

\subsubsection{PRISTUPANJE UGOVORU NA SNAZI U MEĐUNARODNOM SMISLU}

Ako država pristupi ugovoru koji je već na snazi u međunarodnom smislu (između drugih država ugovornica), za nju taj ugovor stupa na snagu s datumom koji je određen u samom ugovoru (na primjer, šezdeset dana nakon pristupanja ili tri/šest mjeseci poslije deponiranja instrumenta ratifikacije).$^{36}$ Ako u ugovoru taj datum nije određen (što će se dogoditi iznimno

31 Članak 24. st. 1. i 2. Bečke konvencije o ugovornom pravu.

32 Stanivuković et. al., op. cit, str. 51.

33 U tom smislu, čl. 16. Zakona o zaključivanju i izvršavanju međunarodnih ugovora.

34 Što proizilaizi iz odredaba čl. 11.-17. Zakona o zaključivanju i izvršavanju međunarodnih ugovora. Također, vidjeti u istom smislu i Etinski, R.; Đajić, S.; Tubić, B., Međunarodno javno pravo, Pravni fakultet, Centar za izdavačku delatnost, Novi Sad, 2017., str. 94.-95.

Članak 25. Bečke konvencije o ugovornom pravu: "1. Ugovor ili deo ugovora primenjuje se privremeno dok ugovor ne stupi na snagu: a) ako je samim ugovorom tako određeno; ili b) ako su se države koje su učestvovale u pregovorima o tome dogovorile na drugi način. 2. Osim ako ugovorom nije drukčije odlučeno ili ako se države koje su učestvovale u pregovorima nisu drukčije dogovorile, privremena primena ugovora ili dela ugovora prema jednoj državi prestaje ako ova država obavesti ostale države između kojih se ugovor privremeno primenjuje o svojoj nameri da ne postane članica ugovora."

36 Primjerice, čl. 61. st. 2. t. a) i b) Konvencije o nadležnosti, merodavnom pravu, priznanju i izvršenju odluka i saradnji u materiji roditeljske odgovornosti i mera za zaštitu dece. 
rijetko), onda će ugovor stupiti na snagu s datumom kada je dala pristanak da bude vezana tim ugovorom. ${ }^{37}$

Međutim, osim tog osnovnog pravila, postoje i određene specifične situacije u kojima je za pristupanje nove država od značaja i stav aktualnih država ugovornica (onih koje već jesu članice tog ugovora). Naime, kada neka država potvrdi (ratificira) određenu hašku konvenciju o međunarodnom privatnom pravu i deponira instrumente ratifikacije depozitaru konvencije (nizozemsko Ministarstvo vanjskih poslova), to ne znači uvijek da je samim tim ona postala država ugovornica odnosne konvencije i da ona automatski vrijedi u odnosima između nje i drugih (ranijih) država ugovornica. Moguće su različite situacije, predviđene samom konvencijom, na koje treba dobro obratiti pozornost.

\subsubsection{ODNOS DRŽAVA ČLANICA PREMA PRISTUPANJU NOVE DRŽAVE MEĐUNARODNOM UGOVORU KOJI JE NA SNAZI}

\section{A) JEDNOSTAVAN PROTEK ROKA}

Najprije, u skladu s osnovnim pravilom, pojedine konvencije ne postavljaju dodatne uvjete za članstvo nove države i za primjenu konvencije u odnosima s drugim državama ugovornicama, osim što se traži da protekne određeni rok. Ipak, i tome treba voditi računa jer je potrebno da taj rok protekne kako bi ugovor stupio na snagu u odnosima između te države i drugih država ugovornica. Na primjer, Haška konvencija o sukobima zakona u pogledu forme testamentarnih odredaba (1961) $)^{38}$ u stavku 2. članka 15. predviđa da će "Konvencija stupiti na snagu, za svaku državu potpisnicu koja je kasnije ratifikuje, šezdesetog dana posle deponovanja njenog ratifikacionog instrumenta". Slično rješenje predviđa i t. a) stavka 2. članka 25. Haškog Protokola o mjerodavnom pravu za obveze uzdržavanja. Treba, dakle, pričekati i tih 60 dana nakon deponiranja instrumenta o potvrđivanju (ratifikaciji) odnosnog međunarodnog ugovora.

\section{B) PREŠUTNA SUGLASNOST ILI (NE)POSTOJANJE IZRIČITOG PRIGOVORA AKTU- ALNIH DRŽAVA ČLANICA}

S druge strane, neke konvencije predviđaju da je dovoljno da se postojeće države ugovornice prešutno suglase s pristupanjem nove države, a ako ne žele prihvatiti pristupanje odnosne države (ne žele da konvencija vrijedi u njihovim međusobnim odnosima), da stave prigovor u određenom roku (sustav prešutne suglasnosti, odnosno, u suprotnom, izričitog protivljenja). Dakle, ako je ranija država ugovornica suglasna s primanjem nove države, ostat će pasivna i na taj način izraziti svoj prešutni pristanak. Ako se pak protivi članstvu nove države, morat će svoje neslaganje izraziti na izričit način, podnošenjem prigovora depozitaru konvencija. $\mathrm{Na}$ primjer, Haška konvencija o ukidanju potrebe legalizacije stranih javnih isprava u stavku 2. članka 12. najprije predviđa da će "Pristupanje imati dejstvo samo u odnosima između države koja pristupa i onih država ugovornica koje ne budu stavile prigovor na to u roku od šest meseci po prijemu saopštenja predviđenog u članu 15. d). Takav prigovor saopštava se Ministarstvu inostranih poslova Holandije". U stavku 3. istog članka rješenje je, zatim, kompletirano odredbom da "Između države koja pristupa i onih država koje ne stave prigovor na to pristupanje,

37 Članak 24. st. 3. Bečke konvencije o ugovornom pravu.

38 Službeni list FNRJ, Međunarodni ugovori i drugi sporazumi, broj 10/1962. 
Konvencija stupa na snagu šezdesetog dana po isteku roka od šest meseci spomenutog u prethodnom stavu". Slično rješenje sadrži i Haška konvencija o nadležnosti, merodavnom pravu, priznanju i izvršenju odluka i saradnji u materiji roditeljske odgovornosti i mera za zaštitu dece (1996), ${ }^{39}$ Konvencija o zaštiti dece i saradnji prilikom međunarodnog usvojenja (1993) ${ }^{40}$ i Konvencija o građanskom postupku.

\section{C) IZJAVE O PRIHVAĆANJU}

Nasuprot tome, pojedine haške konvencije predviđaju drukčiji sustav stupanja na snagu konvencije u odnosima aktualnih država ugovornica i države koja pristupa konvenciji. Prema tom sustavu, država ugovornica koja prihvaća pristupanje nove države ugovornice treba dati izričitu izjavu o prihvaćanju pristupanja depozitaru konvencije. Ako to ne učini, konvencija neće vrijediti u njihovim međusobnim odnosima. Dakle, u ovom slučaju se zahtijeva da država ugovornica bude aktivna i izričito izjavi da prihvaća pristupanje nove države ugovornice, a ostane li pasivna i ne dâ izjavu, smatrat će se da ne prihvaća pristupanje odnosne države. Na primjer, Haška konvencija o građanskopravnim aspektima međunarodne otmice dece (1980) u st. 4. čl. 38. predviđa da će "Pristupanje biti punovažno samo u odnosima između države pristupnice i onih država ugovornica koje budu izjavile da prihvataju pristupanje”, a u stavku 5. istog članka da će "Konvencija stupiti na snagu između države koja pristupa i države koja je izjavila da prihvata pristupanje prvog dana trećeg kalendarskog meseca nakon polaganja izjave o prihvatanju". Ovo rješenje prihvaćeno je i u st. 4. i 5. čl. 18. Haške konvencije o zakonu koji se primenjuje na saobraćajne nezgode (1971), kao i u st. 4. i 5. čl. 39. Haške konvencije o pribavljanju u inostranstvu dokaza u građanskim i trgovačkim stvarima (1970). ${ }^{41}$

S obzirom na to da je Republika Srbija ugovornica ovih triju konvencija, potrebno je ukazati da ovaj posljednji sustav zahtijeva posebnu pozornost nadležnih ministarstava i kontinuirano praćenje članstva novih država u njima. Naime, pri svakom pristupanju nove države nekoj od ovih konvencija, potrebno je razmotriti stav Republike Srbije i ako je potrebno, pravodobno dati izjavu o prihvaćanju pristupanja. Problem je u tome što distrakcija ili inertnost koji rezultiraju nedavanjem izjave (iako bi inače bila dana), dovode do toga da određena konvencija ne vrijedi između Republike Srbije, primjerice, i druge države koja je kasnije pristupila. Recimo, bilo je slučajeva da se živjelo u uvjerenju da npr. Haška konvencija o međunarodnoj otmici djece (1980) vrijedi između Republike Srbije i druge države (jer se obraćala pozornost samo na podatak koje su države ugovornice te Konvencije, ali ne i na činjenicu da je ta država kasnije pristupila Konvenciji, a da Republika Srbija, kao ranija država ugovornica, nije dala izjavu o prihvaćanju pristupanja). Tijekom rada Saveta za međunarodno privatno pravo Vlade Republike Srbije (2011.-2016.) ti propusti su otklonjeni ukazivanjem nadležnom ministarstvu na problem i dane su izjave o prihvaćanju pristupanja pojedinih država. Međutim, treba imati na umu da posao time nije završen i da svako pristupanje nove države nekoj od ovih konvencija zahtijeva reakciju nadležnih ministarstava (ministarstva u čijoj je nadležnosti odnosna konvencija i Ministarstva spoljnih poslova) i odlučivanje o davanju izjave o prihvaćanju pristupanja. Isto to, mutatis mutandis vrijedi i kada je riječ o (haškim) konvencijama koje članstvo nove 
države vezuju za sustav prešutne suglasnosti, odnosno, izričitog protivljenja. I tada ministarstvo, u čiju nadležnost pripada konkretna konvencija, treba u suradnji s nadležnim državnim tijelima i Ministarstvom spoljnih poslova Republike Srbije zauzeti stav prema pristupanju nove države i ponašati se na način koji smatra odgovarajućim. ${ }^{42}$

\subsubsection{PRISTUPANJE MEĐUNARODNOM UGOVORU KOJI NIJE STUPIO NA SNAGU U MEĐUNARODNOM SMISLU}

Ako Republika Srbija pristupi međunarodnom ugovoru koji nije stupio na snagu u međunarodnom smislu, moguće je razlikovati tri situacije.

Prva situacija odnosi se na slučaj kada je Republika Srbija posljednja u grupi država koje daju potreban broj ratifikacija da bi ugovor stupio na snagu u međunarodnom smislu. To znači da su druge države već ratificirale konkretni međunarodni ugovor, ali da nedostaje još jedna ratifikacija (potvrđivanje) za njegovo stupanje na snagu, a upravo je daje Republika Srbija. U tom slučaju, stupanje na snagu ugovora u međunarodnom smislu poklapa se s njegovim stupanjem na snagu u unutrašnjem pravnom poretku Republike Srbije. Kao primjer za ovu situaciju možemo navesti treću ratifikaciju (posljednju, potrebnu za stupanje ugovora na snagu u međunarodnom smislu) tadašnje FNR Jugoslavije Haškoj konvenciji o sukobu zakona u pogledu testamentarnih odredaba iz 1961. godine. Konvencija je stupila na snagu u međunarodnom smislu i u unutrašnjem pravnom poretku FNRJ 5. siječnja 1964. Isto tako, i nedavno pristupanje Republike Srbije Haškom Protokolu (2007) predstavlja dobar primjer te tzv. "kritične ratifikacije", kako je nazvana u ovom radu. Republika Srbija je deponirala instrumente ratifikacije 10. travnja 2013. godine i to je bila druga ratifikacija (posljednja, potrebna za stupanje Protokola na snagu, jer je prva bila od strane EU-a). Protokol je, u skladu s rokovima koji su sadržani u njegovim odredbama, stupio na snagu i u međunarodnom smislu i u unutrašnjem poretku Republike Srbije 1. kolovoza 2013. godine.

Druga situacija (nazvat ćemo je "obična" ratifikacija) odnosi se na slučaj kada Republika Srbija potvrdi (ratificira) međunarodni ugovor, a nakon toga protekne više godina do njegova stupanja na snagu u međunarodnom smislu (dok se ne postigne potreban broj ratifikacija). ${ }^{43}$

Treća, odnosi se na slučaj da Republika Srbija potvrdi (ratificira) određeni međunarodni ugovor, a da on nikad ne stupi na snagu jer ne bude ostvaren potreban broj ratifikacija (označili smo je u ovom radu kao "uzaludnu" ratifikaciju). ${ }^{44}$

42 Samo reagiranje u formalnopravnom smislu u nadležnosti je Ministarstva spoljnih poslova - prema st. 1. čl. 15. Zakona o zaključivanju i izvršavanju međunarodnih ugovora, "Ministarstvo nadležno za poljne poslove stara se o izradi i razmeni instrumenata o potvrđivanju, deponovanju instrumenata o potvrđivanju višestranog međunarodnog ugovora i izvršenju drugih međunarodnim ugovorom predviđenih radnji u vezi sa obaveštavanjem druge strane ugovornice o stupanju međunarodnog ugovora na snagu."

43 Primjeri za ovu situaciju su brojni: tako, Bečka konvencija o ugovornom pravu (1969), kod nas je objavljena 1972. godine, a stupila je na snagu u međunarodnom smislu 1980. godine; Bečka konvencija o sukcesiji država u odnosu na međunarodne ugovore kod nas je objavljena 1980. godine, a stupila je na snagu u međunarodnom smislu 1996. godine; Konvencija UN-a o međunarodnoj prodaji robe objavljena je kod nas 1984. godine, a stupila je na snagu u međunarodnom smislu 1988. godine (Službeni list SFRJ, Međunarodni ugovori, broj 10-1/1984) i dr.

44 Kao što je to, na primjer, bio slučaj s Konvencijom o upisu prava na brodovima u gradnji (1967), koju je ranija SFRJ ratificirala 1971. godine nikada nije stupila na snagu zbog nedovoljnog broja ratifikacija. 
Praktični problemi koji se javljaju u posljednjim dvjema situacijama ("obična" i "uzaludna" ratifikacija) tiču se (ne)primjene međunarodnog ugovora. Naime, sam zakon o potvrđivanju nekog međunarodnog ugovora najčešće stupa na snagu na osnovi opće odredbe o vacatio legis (osmog dana po objavljivanju), osim ako je u njemu nešto drugo određeno. No, znači li to da su istodobno stupile na snagu i odredbe međunarodnog ugovora sadržane u njemu? Drugim riječima, trebaju li sudovi primjenjivati dani međunarodni ugovor iako on još nije stupio na snagu u međunarodnom smislu? Odgovor je, kako smo već rekli - ne. Treba smatrati da je za stupanje na snagu ugovora u unutrašnjem pravnom poretku uvjet da je ugovor prethodno stupio na snagu u međunarodnom smislu. Ne treba pretpostaviti, dakle, da zakonodavac želi obvezati domaće sudove na primjenu ugovora prije nego što on stupi na snagu u odnosima određenog broja (ili rjeđe, svih) država ugovornica (osim ako nije riječ o privremenoj primjeni ugovora. Klauzulu o vacatio legis u Zakonu o ratifikaciji (da Zakon stupa na snagu osmog dana po objavljivanju) treba tumačiti tako da onaj dio Zakona koji sadrži tekst međunarodnog ugovora stupa na snagu pod odložnim uvjetom, odnosno nakon stupanja na snagu ugovora u međunarodnom smislu. ${ }^{45}$

Nerazlikovanje stupanja na snagu Zakona o potvrđivanju međunarodnog ugovora i samog teksta međunarodnog ugovora dovodilo je donedavno do problema u praksi. Kao ilustracija, mogu se navesti problemi u primjeni Sporazuma o pitanjima sukcesije bivše SFRJ. Naime, člankom 3. Zakona o potvrđivanju sporazuma o pitanjima sukcesije predviđeno je da "Ovaj zakon stupa na snagu osmog dana od dana objavljivanja u 'Službenom listu SRJ - Međunarodni ugovori”, dok s druge strane, stavak 1. članak 12. Sporazuma predviđa da “Ovaj Sporazum stupa na snagu tridesetog dana nakon deponovanja petog instrumenta ratifikacije." Datumi stupanja na snagu u jednom i u drugom slučaju bili su prilično međusobno udaljeni - u prvom, osmi dan nakon objavljivanja u "Službenom listu SRJ" bio je 11. srpnja 2002. godine, dok je u drugom, trideseti dan nakon deponiranja petog instrumenta ratifikacije bio 2. lipnja 2004. godine (nakon što je Republika Hrvatska, kao peta država, ratificirala Sporazum u ožujku 2004., zatim, deponirala instrumente ratifikacije početkom svibnja iste godine i Sporazum stupio na snagu nakon predviđenog roka od trideset dana). Međutim, u intervalu od objavljivanja ugovora u "Službenom listu SRJ - Međunarodni ugovori" do njegova stupanja na snagu u međunarodnom smislu (razdoblje od 11. srpnja 2002. do 2. lipnja 2004.), veći broj osoba iz drugih novostvorenih država s prostora bivše SFRJ podnio je pred sudovima Republike Srbije zahtjeve za povratom imovine na osnovi odredaba Sporazuma. Viši trgovinski sud u nekoliko je svojih odluka odbio takve zahtjeve s pozivom na to da Sporazum još nije stupio na snagu u međunarodnom smislu, ali su ih pojedini (tadašnji) općinski i okružni sudovi usvajali s obrazloženjem da je "Sporazum objavljen i stupio na snagu u roku od osam dana posle objavljivanja”, imajući u vidu datum iz srpnja 2002. godine, i smatrajući ga (pogrešno) relevantnim za početak primjene Sporazuma. ${ }^{46}$

Isto tako, problemi su mogli nastajati (u kraćem vremenskom intervalu) i zbog toga što Zakon o potvrđivanju međunarodnog ugovora i predviđeni opći rok o vacatio legis od 8 dana o njegovu stupanju na snagu često bivaju u neskladu s rokom koji je predviđen u samom ugo-

45 Jedino ako je u prijelaznim odredbama Zakona o ratifikaciji izričito određeno da se odredbe ugovora imaju primjenjivati i prije njegova stupanja na snagu u međunarodnom smislu, trebalo bi smatrati da su sudovi obvezni to činiti.

46 Vidjeti detaljnije, Živković, M., Tumačenje članova 2, 4. i 7. priloga “G” sporazuma o pitanjima sukcesije u praksi naših sudova i drugih organa, Liber Amicorum: Dobrosav Mitrović, Spoljnotrgovinska arbitraža pri Privrednoj komori Srbije, Beograd, 2007., str. 691.721. 
voru za stupanje na snagu ugovora u odnosu na državu koja mu pristupa (npr. 60 dana ili 3 mjeseca ili 6 mjeseci). I u tom slučaju, nakon isteka roka od 8 dana ne bi trebalo primjenjivati odnosni međunarodni ugovor, već poslije isteka roka koji predviđaju odredbe samog ugovora.

Međutim, ono što je najvažnije, problemi te vrste ne bi se trebali više javljati u praksi sudova Republike Srbije nakon donošenja Zakona o zaključivanju i izvršavanju međunarodnih ugovora. U st. 2. čl. 16. Zakona predviđeno je da "Ministarstvo nadležno za spoljne poslove u 'Službenom glasniku Republike Srbije - Međunarodni ugovori' objavljuje obaveštenje o datumu stupanja na snagu međunarodnog ugovora". Na taj način, preko te posebne obavijesti, izbjegavaju se "nedoumice" u vezi sa stupanjem na snagu međunarodnog ugovora - Ministarstvo spoljnih poslova u "Službenom glasniku" izričito navodi relevantni datum od kojega odnosni ugovor vrijedi u pravnom sustavu Republike Srbije. Sudovi i druga nadležna tijela tako su u prigodi jasno doznati otkada određeni međunarodni ugovor treba primijeniti. Kako to konkretno izgleda u praksi, možemo vidjeti na primjeru Haške konvencije o nadležnosti, mjerodavnom pravu, priznanju, ovrsi i suradnji u odnosu na roditeljsku odgovornost i o mjerama za zaštitu djece (1996) koja je nedavno (1. studenoga 2016.) stupila na snagu u Republici Srbiji. Postupak se odvijao na sljedeći način: Konvencija je, najprije, potvrđena (ratificirana) u Narodnoj skupštini 3. studenoga 2015. godine; zatim je objavljena u "Službenom glasniku Republike Srbije” (2015); potom su instrumenti ratifikacije deponirani 15. siječnja 2016. godine kod depozitara - nizozemskog Ministarstva inozemnih poslova. Onda je Ministarstvo spoljnih poslova objavilo Obaveštenje o datumu stupanja na snagu Konvencije. ${ }^{47} \mathrm{Zbog}$ značaja ovog rješenja, obavijest navodimo u cjelini:

"Na osnovu člana 16. stav 2. Zakona o zaključivanju i izvršavanju međunarodnih ugovora ('Službeni glasnik RS', broj 32/2013),

Ministarstvo spoljnih poslova Republike Srbije

OBJAVLJUJE

Da će Konvencija o nadležnosti, merodavnom pravu, priznanju i izvršenju odluka i saradnji u materiji roditeljske odgovornosti i mera za zaštitu dece, sačinjena u Hagu 19. oktobra 1996. godine, a objavljena u 'Službenom glasniku Republike Srbije - Međunarodni ugovori', broj 20/2015 od 9. novembra 2015. godine, stupiti na snagu za Republiku Srbiju 1. novembra 2016. godine.

U Beogradu, 19. januara 2016. godine

Ministarstvo spoljnih poslova Republike Srbije."

Dakle, sudovi u Republici Srbiji i druga tijela bili su vrlo jasno obaviješteni u "Službenom glasniku RS” o datumu otkada ova Konvencija stupa na snagu u pravnom sustavu Republike Srbije, odnosno, otkada je treba primjenjivati. Treba se nadati da će Ministarstvo spoljnih poslova nastaviti ažurno obavljati ovaj iznimno koristan posao. Pritom je, pri objavljivanju obavijesti o stupanju na snagu međunarodnog ugovora u pravnom sustavu Republike Srbije, u neku ruku njegova situacija "olakšana" kada je riječ o međunarodnim ugovorima koji su već na snazi i kojima Srbija pristupa. Ali treba očekivati da će Ministarstvo pratiti i međunarodne ugovore kojima Srbija pristupi, a koji još nisu stupili na snagu (u međunarodnom smislu) zbog 
nedovoljnog broja ratifikacija. U tom slučaju, zadatak Ministarstva je nešto "teži” jer treba kontinuirano pratiti aktualno stanje (broj ratifikacija) i voditi računa o tome kada međunarodni ugovor stupa na snagu u međunarodnom smislu (kad skupi dovoljan broj ratifikacija predviđen samim ugovorom, odnosno kada neka druga država bude dala "kritičnu ratifikaciju") i da nakon toga objavi odgovarajuću obavijest u "Službenom glasniku RS". U svakom slučaju, rješenje predviđeno člankom 16. st. 2. Zakona o zaključivanju i izvršavanju međunarodnih ugovora za pohvalu je jer pruža nužnu sigurnost u vezi s određivanjem datuma stupanja na snagu međunarodnih ugovora u pravnom sustavu Republike Srbije.

Ako se tome doda da je stavkom 1. članka 15. istog Zakona Ministarstvu spoljnih poslova, među ostalim, stavljeno u nadležnost da se “(...) stara o (...) izvršenju drugih međunarodnim ugovorom predviđenih radnji u vezi sa obaveštavanjem druge strane ugovornice o stupanju međunarodnog ugovora na snagu", uviđamo da, kada je riječ o stupanju na snagu višestranog međunarodnog ugovora, ovo Ministarstvo vrši dvostruki posao, figurativno rečeno - i "prema unutra" i "prema van". "Prema unutra”, na osnovi st. 2. čl. 16., obavještava u "Službenom glasniku RS” naše sudove i druga nadležna tijela o stupanju na snagu međunarodnog ugovora, a prema st. 1. čl. 15., obavještava drugu stranu ugovornicu, odnosno druge strane ugovornice o stupanju na snagu međunarodnog ugovora.

Podacima o važećim međunarodnim ugovorima raspolaže Ministarstvo spoljnih poslova Srbije ili drugo ministarstvo u čijoj je nadležnosti područje koja je predmet ugovora. ${ }^{48}$ Osim toga, i na mrežnim stranicama međunarodnih organizacija u okviru kojih su prihvaćeni pojedini višestrani ugovori, mogu se naći relevantni podaci o tim ugovorima (ažuriran popis država članica, sam tekst ugovora na jeziku na kojem je zaključen, datumi stupanja na snagu ugovora u međunarodnom smislu i u odnosu na svaku državu članicu, lista izjava, rezervi i sl.).

\section{MEĐUNARODNI UGOVORI KAO IZVOR MEĐUNARODNOG PRIVATNOG PRAVA - REDOSLIJED U PRIMJENI}

Kako je poznato, međunarodno privatno pravo ima dvije vrste izvora: unutrašnje (ustav, Zakon o rješavanju sukoba zakona, drugi zakoni) i međunarodne (dvostrani i višestrani međunarodni ugovori). Ta okolnost može dovesti do izvjesnih problema pri rješavanju konkretnih pravnih pitanja s međunarodnim elementom. Može se, naime, dogoditi da isto pravno pitanje bude regulirano dvjema ili čak trima vrstama izvora čije se odredbe međusobno sadržajno razlikuju. Zadatak suda ili drugog tijela primjene prava, koji svaki put trebaju točno odrediti pravni propis koji će primijeniti, u tom slučaju je otežan s obzirom na to da utvrđivanje relevantnog izvora katkad može biti komplicirana operacija. Zbog toga su formulirana pravila koja govore o redoslijedu u primjeni spomenutih izvora (prvenstvu primjene, njihovoj hijerarhiji). Ta pravila

48 Originalni primjerci potpisanih međunarodnih ugovora evidentiraju se i čuvaju u ministarstvu nadležnom za vanjske poslove. Vidjeti čl. 25. Zakona o zaključivanju i izvršavanju međunarodnih ugovora. 
sadržana su u članku 194. Ustava Srbije (2006), ${ }^{49}$ članku 3. Zakona o rješavanju sukoba zakona s propisima drugih zemalja (ZRSZ) ${ }^{50}$ i članku 30. Bečke konvencije o ugovornom pravu (1969).

Pitanje redoslijeda u primjeni može se postaviti na tri razine: najprije, kada je riječ o odnosu unutrašnjih i međunarodnih izvora, zatim, kada je riječ o odnosu samih međunarodnih izvora (unutar međunarodnih izvora), i napokon, kada je riječ o međusobnom odnosu unutrašnjih izvora (unutar unutrašnjih izvora). Ova posljednja razina neće biti predmet naših razmatranja.

\subsection{ODNOS UNUTRAŠNJIH I MEĐUNARODNIH IZVORA}

Odnos unutrašnjih i međunarodnih izvora različit je u ovisnosti o tome o kojem je unutrašnjem izvoru riječ. Jedno rješenje je predviđeno ako je to Ustav Srbije (2006), a drugo, ako su to ZRSZ ili drugi zakoni.

Ustav je pravni akt najviše pravne snage u jednoj državi i svi drugi izvori, uključujući i međunarodne ugovore, morali bi biti u skladu s njim. Ustav Srbije (2006) to pravilo jasno proklamira, izričito predviđajući da "potvrđeni međunarodni ugovori ne smeju biti u suprotnosti sa Ustavom". ${ }^{51}$ Drugim riječima, odredbe Ustava imaju prednost u odnosu na odredbe potvrđenih međunarodnih ugovora. Prema st. 2. čl. 58. Zakona o Ustavnom sudu, ${ }^{52}$ "Odredbe potvrđenog međunarodnog ugovora za koje je odlukom Ustavnog suda utvrđeno da nisu u saglasnosti sa Ustavom, prestaju da važe na način predviđen tim međunarodnim ugovorom i opšteprihvaćenim pravilima međunarodnog prava."

Glede odnosa međunarodnih ugovora i zakona, situacija je drukčija - "zakoni i drugi opšti akti doneti u Republici Srbiji ne smeju biti u suprotnosti sa potvrđenim međunarodnim ugovorima i opšteprihvaćenim pravilima međunarodnog prava". ${ }^{33}$ Također, i sam Zakon o rešavanju sukoba zakona u članku 3. govori o prvenstvu primjene međunarodnih ugovora u odnosu na odredbe koje su u njemu sadržane. ${ }^{44}$ Kako se navodi u njegovu članku 3., "Odredbe ovog zakona ne primenjuju se na odnose iz člana 1 ovog zakona ako su regulisani (...) međunarodnim ugovorom".

49 Ustav Republike Srbije, Službeni glasnik RS, broj 98/2006. Iako je naslov članka 194. Ustava ambiciozan ("Hijerarhija domaćih i međunarodnih opštih pravnih akata"), njegovim odredbama ipak nisu obuhvaćene sve situacije u kojima se postavlja pitanje redoslijeda u primjeni izvora međunarodnog privatnog prava. SRJ, broj 46/1996 i Službeni glasnik RS, broj 46/2006.

51 Članak 194. st. 4. Ustava Srbije.

52 Zakon o Ustavnom sudu, Službeni glasnik RS, broj109/2007.

53 Članak 194. st. 5. Ustava Srbije.

54 Članak 3. ZRSZ-a danas je suvišan s obzirom na to da sam Ustav Srbije (2006) daje prednost u primjeni međunarodnim ugovorima u odnosu na zakone. Međutim, ne treba zaboraviti da je ZRSZ donesen u vrijeme važenja Ustava SFRJ iz 1974. godine prema kojem su međunarodni ugovori i zakoni bili tretirani kao pravni akti jednake pravne snage. Otuda je propisivanje članka 3. ZRSZ-a u to vrijeme bilo opravdano. Riječ "savezni" u tekstu člana 3. danas treba zanemariti. 
Ove odredbe o prvenstvu primjene međunarodnih ugovora u odnosu na zakone osnova su već spomenutog pravila "najprije provjeriti". ${ }^{55}$ Pritom, s obzirom na to da se broj međunarodnih ugovora u međunarodnom privatnom pravu Republike Srbije stalno povećava, ovo pravilo sve više dobiva na značaju. Zbog toga ćemo ga ponoviti. Dakle - svaki pravnik koji rješava određeno pravno pitanje iz područja međunarodnog privatnog prava, prije nego što konzultira zakonske odredbe, mora najprije provjeriti postoji li između Republike Srbije i strane države s kojom je odnos povezan, dvostrani ili višestrani ugovor u konkretnoj pravnoj stvari. To je osnovno pravilo primjene normi međunarodnog privatnog prava i njega nikad ne smijemo zaboraviti. Zanemarimo li ga, može nam se dogoditi da spor rješavamo prema normama međunarodnog privatnog prava sadržanim u zakonima, koje su drukčije od onih sadržanih u međunarodnim ugovorima. Na taj način, riskirali bismo pogreške (različite vrste), kako tijekom vođenja postupka, tako i u konačnici. Dojam je, također, da ovo elementarno pravilo naši sudovi često zanemaruju i da otuda kreću prve nevolje pri rješavanja sporova iz međunarodnog privatnog prava. ${ }^{56} \mathrm{Na}$ primjer, ako bi bila riječ o razvodu braka supružnika, srpskog i francuskog državljanina koji su živjeli u Francuskoj, pri čemu srpski državljanin ima boravište u Republici Srbiji, moglo bi se primijeniti različito pravo na razvod u ovisnosti o tome koji bi izvor bio primijenjen. Zakon o rješavanju sukoba zakona s propisima drugih zemalja u članku 35. predviđa da će se u slučaju nepostojanja zajedničkog nacionalnog prava primijeniti pravo Republike Srbije ako je jedan od supružnika državljanin Republike Srbije. S druge strane, članak 8. Konvencije između SFRJ i Republike Francuske o nadležnosti i o zakonu koji se primjenjuje u području osobnog i obiteljskog prava $(1971)^{57}$ predviđa da se u slučaju nepostojanja zajedničkog nacionalnog prava na razvod primjenjuje lex domicilii comuni, ili u nedostatku ovog, lex ultimi domicilii comuni supružnika, što u oba slučaja vodi primjeni francuskog prava.

\subsection{ODNOS IZMEĐU MEĐUNARODNIH UGOVORA}

Kada je riječ o međusobnom odnosu međunarodnih izvora, situacija je sljedeća. Primjena uzastopnih međunarodnih ugovora o istom predmetu regulirana je člankom 30. Bečke konvencije o ugovornom pravu. Pritom ova Konvencija ne pravi razliku između dvostranih i višestranih međunarodnih ugovora. To razlikovanje može se (ali ne mora) vršiti u samim međunarodnim ugovorima na koje se Konvencija odnosi. Na primjer, u određenom članku nekog međunarodnog ugovora (recimo, haških konvencija) često se govori o njezinu odnosu prema drugim medunarodnim instrumentima. ${ }^{58} \mathrm{U}$ okviru toga, može se poimence spomenuti određena (starija, konkurentska) konvencija čije odredbe najčešće prestaju vrijediti, u cjelini ili djelimice, a uz to (u sljedećem stavku ili članku) može se posebno istaknuti i njezin odnos prema dvostranim međunarodnim ugovorima u istoj pravnoj stvari, koji su na snazi između država članica. ${ }^{59}$

55 Vidjeti supra ad. 2.1.

56 Vidjeti detaljno o problemu, Živković, M., Međunarodno privatno parvo - neprijatna nepoznanica naših sudova?, Pravni život, Savez udruženja pravnika Srbije, Beograd, 7-8, 1992., str. 1083.-1107.

57 Službeni list SFRJ, broj 55/1972. Konvencija je stupila na snagu 1. prosinca 1972.

58 Primjerice, čl. 19. Haškog protokola o mjerodavnom pravu za obveze izdržavanja. Članak 52. Konvencije o nadležnosti, mjerodavnom pravu, priznanju i izvršenju odluka i suradnji u materiji roditeljske odgovornosti i mjera za zaštitu djece. 
Dakle, osnovno je rješenje da u samom međunarodnom ugovoru može biti sadržano pravilo o tome koji će se ugovor primjenjivati. ${ }^{60}$ Ta odredba može davati prednost u primjeni drugim ugovorima bez obzira na to jesu li zaključeni prije ili poslije tog ugovora. ${ }^{61} \mathrm{Ipak}$, takve odredbe su iznimka. Mnogo su češće u međunarodnom ugovoru odredbe kojima se stavljaju izvan snage raniji međunarodni ugovori o istom predmetu. Na primjer, člankom 49. Haške konvencije o međunarodnoj naplati alimentacije i drugih oblika obiteljskog uzdržavanja(2007) ${ }^{62}$ stavljene su izvan snage odredbe Konvencija UN-a o ostvarivanju alimentacijskih zahtjeva u inozemstvu (tzv. Njujorške konvencije, 1956) ${ }^{63}$ između država članica obiju konvencija. ${ }^{64}$

Ako u međunarodnom ugovoru nema pravila o tome koji će se ugovor primjenjivati, raniji ugovor se primjenjuje samo ako su njegove odredbe suglasne s odredbama kasnijeg ugovora. A contrario, ako te odredbe nisu suglasne, primjenjuju se odredbe kasnijeg ugovora (princip lex posterior). ${ }^{65}$

Ova rješenja vrijede i kad su posrijedi stare i nove verzije istog ugovora. ${ }^{66}$ Također, između država od kojih je jedna ratificirala oba ugovora o istom predmetu, a druga samo jedan od tih ugovora, vrijedi onaj ugovor ili ona njegova verzija koju su obje države ratificirale. ${ }^{67}$

U našoj teoriji često se spominje pravilo da dvostrani ugovor kao lex specialis ima prednost u primjeni nad višestranim ugovorom bez obzira na vrijeme potvrđivanja ili objavljivanja jednog ili drugog ugovora. ${ }^{68}$ Međutim, kako smo napomenuli, Bečka konvencija u članku 30. ne pravi razliku između dvostranih i višestranih ugovora. Dakle, ako u kasnijem ugovoru postoji izričita odredba o prvenstvu primjene jednog ili drugog ugovora, nje se treba pridržavati; no, ako takve odredbe nema, treba primijeniti odredbe kasnijeg ugovora bez obzira na to je li riječ o dvostranom ili višestranom ugovoru. Na primjer, treba pretpostaviti da višestrani ugovor koji sadrži drukčije odredbe u istoj pravnoj stvari, a koji su iste države zaključile poslije dvostranog, derogira odredbe ovog drugog u onom dijelu u kojem su suprotne novom ugovoru. I obrnuto, kasniji dvostrani ugovor koji sadrži drukčije odredbe o istom predmetu derogira raniji višestrani ugovor između država ugovornica koje su zaključile dvostrani ugovor. Ovo pravilo vrijedi neovisno o tome je li riječ o uzastopnim dvostranim ili višestranim ugovorima $\mathrm{u}$ istoj pravnoj stvari.

Međutim, i kraj ovih jasnih odredaba članka 30. Bečke konvencije, među našim pravnicima duboko je ukorijenjeno uvjerenje da dvostrani ugovor, kao lex specialis, uvijek derogira odred-

60 Članak 30. st. 2. Bečke konvencije o ugovornom pravu.

61 Na primjer, čl. 32. Haške konvencije o dostavi u inozemstvo sudskih i izvansudskih dokumenata u građanskim ili trgovačkim stvarima.

62 Hague Convention of 23 November 2007 on the International Recovery of Child Support and Other Forms of Family Maintenance. https://assets.hcch.net/docs/14e71887-0090-47a3-9c49-d438eb601b47.pdf. Pristupljeno 12. listopada 2018.

63 Službeni list FNRJ, Međunarodni ugovori i drugi sporazumi, broj 2/1960.

64 Vidjeti Marjanović, S., Međunarodno ostvarivanje izdržavanja članova porodice - birajući između Konvencije UN (1956) i Haške konvencije (2007), Zbornik radova Pravnog fakulteta Univerziteta u Nišu, broj 78, 2018., str. 235.-254.

65 Članak 30. st. 3. Bečke konvencije o ugovornom pravu.

66 Jezdić, M., Međunarodno privatno pravo I, Naučna knjiga, Beograd, 1980., str. 40.

67 Avramov, S.; Kreća, M., Međunarodno javno pravo, Beograd, 2009., str. 470. Na primjer, čl. 29. Konvencije o građanskom postupku (u odnosu na države ugovornice Konvencije o građanskom postupku iz 1905. godine).

68 Vidjeti posebno Dika, M.; Knežević, G.; Stojanović, S., Komentar Zakona o međunarodnom privatnom i procesnom pravu, Nomos, Beograd, 1991., str. 14. Varadi et al., op. cit. str. 78. 
be višestranog ugovora o istom predmetu, bez obzira na vrijeme njihova donošenja. Možda je razlog ovako pojednostavnjenog razmišljanja okolnost što odredbe višestranih međunarodnih ugovora koje govore o odnosu prema drugim međunarodnim instrumentima često predviđaju da države ugovornice mogu nastaviti primjenjivati ranije zaključen dvostrani ugovor u svojim međusobnim odnosima. Takvo rješenje sadrže, na primjer, pojedine haške konvencije. ${ }^{69} \mathrm{Me}-$ đutim, učestalost takvog rješenja nije argument za njegovu apsolutizaciju. Postoje i međunarodni ugovori koji to rješenje dopuštaju samo uz ispunjenje određenih uvjeta ${ }^{70}$ ili ga čak izričito zabranjuju. ${ }^{71}$ Otuda, treba pomno pročitati odredbe svakog međunarodnog ugovora koje određuju odnos prema ranije zaključenim dvostranim međunarodnim ugovorima i zaboraviti na mentalni refleks dvostrani ugovor - višestrani ugovor - lex specialis.

Pri uspoređivanju tekstova uzastopnih ugovora treba biti iznimno oprezan, posebno kada je riječ o utvrđivanju njihova područja primjene i supsumpcije (svrstavanja, podvođenja) pravnog pitanja pod odredbe ugovora. Analizom odredaba i jednog i drugog ugovora moramo se uvjeriti da je riječ o istom pravnom pitanju koje je sadržajno različito regulirano u oba teksta i provjeriti ostavlja li ugovor koji ima prvenstvo u primjeni možda prostor i za primjenu odredaba onog drugog ugovora. Naime, može se dogoditi da se uzastopni ugovori samo djelimice poklapaju u vezi s područjem primjene (iako se prema svojim nazivima odnose na istu pravnu stvar), tako da se u određenom dijelu mogu primijeniti i odredbe ugovora koji nema prvenstvo u primjeni. Praktično, zbog toga što u određenom području postoji kasniji ugovor, ne treba automatski odbaciti svaku mogućnost primjene i ranijeg ugovora o istom predmetu čije su članice obje države. ${ }^{72}$ Pravilo lex posterior, prema tome, ne treba mehanički primjenjivati i razmišljati na relaciji "ili... ili", nego pomno provjeravati područje primjene obaju ugovora i stalno imati na umu mogućnost njihove kumulativne primjene (“i... i”). Na primjer, između Srbije i Belgije na snazi je Konvencija o uzajamnom priznanju i izvršenju sudskih odluka o izdržavanju (1973), ${ }^{73}$ a obje države su članice i višestrane Konvencije o ostvarivanju alimentacijskih zahtjeva u inozemstvu (1956). Prednost u primjeni kasnijeg ugovora ne znači da raniju Konvenciju treba nepročitanu gurnuti u stranu i rješenje tražiti samo u dvostranom Sporazumu. Naprotiv, treba pozorno razmotriti i odredbe Konvencije i utvrditi pruža li ona kakvu dodatnu mogućnost u području priznanja i izvršenja odluke o izdržavanju koja nije predviđena Sporazumom. Ovo utoliko prije što prema članku 2. Konvencije pravna sredstva koja ona predviđa dopunjuju sva druga pravna sredstva koja postoje prema domaćem i međunarodnom pravu.

69 Članak 18. Haške konvencije o ovlaštenjima nadležnih tijela i mjerodavnom pravu za zaštitu maloljetnika (Convention of 5 October 1961 concerning the powers of authorities and the law applicable in respect of the protection of infants). https://www. hcch.net/en/instruments/conventions/full-text/?cid=39. Pristupljeno 10. listopada 2018.

70 Na primjer, čl. 52. Haške konvencije o međunarodnom ostvarivanju izdržavanja djece i drugih članova obitelji; čl. 36. Haške konvencije o građanskopravnim aspektima međunarodne otmice djece; čl. 8. Haške konvencije o ukidanju potrebe legalizacije stranih javnih isprava.

71 Na primjer, čl. 39. Haške konvencije o nasljeđivanju zaostavštine umrlih osoba (Convention of 2 October 1973 Concerning the International Administration of the Estates of Deceased Persons. https://www.hcch.net/en/instruments/conventions/fulltext/?cid=83. Pristupljeno 12. studenoga 2018.); čl. 24. Haške konvencije o priznanju i izvršenju sudskih odluka u građanskim i trgovačkim stvarima (Convention of 1 February 1971 on the Recognition and Enforcement of Foreign Judgments in Civil and Commercial Matters. https://www.hcch.net/en/instruments/conventions/full-text/?cid=78. Pristupljeno 12. studenoga 2018.). 


\section{DVOSTRANI UGOVORI O PRAVNOJ POMOĆI U GRAĐANSKIM STVARIMA NA SNAZI IZMEĐU REPUBLIKE SRBIJE I DRŽAVA ČLANICA EU-a}

U Republici Srbiji na snazi je velik broj dvostranih međunarodnih ugovora koji uređuju pojedina pitanja međunarodnog privatnog prava. Ti ugovori se javljaju pod različitim imenima, tako da u tom području postoji prilična šarolikost. Međutim, moglo bi se reći da norme međunarodnog privatnog prava najčešće sadrže ugovori koji nose naziv "ugovor o pravnoj pomoći”, "ugovor o pravnom saobraćaju" ili "sporazumi o priznanju i izvršenju odluka u građanskoj/ porodičnoj materiji”. Osim njih, takve norme sadrže i "konzularne konvencije" i "ugovori o trgovini i plovidbi” (ovi posljednji su starijeg datuma). U ovim ugovorima (posebno onima o pravnoj pomoći) nalaze se norme o međunarodnoj sudskoj nadležnosti i kolizijske norme (uglavnom za statusne, nasljedne i obiteljske odnose), ${ }^{74}$ kao i odredbe o priznanju i izvršenju stranih sudskih i arbitražnih odluka. ${ }^{75}$ Osim toga, u mnogima od njih mogu se sresti odredbe o pravima stranaca, na primjer, da stječu svojinu (pravnim poslovima inter vivos ili nasljeđivanjem) ili da obavljaju privrednu djelatnost na teritoriju domaće države. ${ }^{76}$ Napokon, ugovori o pravnoj pomoći sadrže i norme kojima se uređuju pitanja izvođenja dokaza, legalizacije isprava, oslobađanja od obveze polaganja aktorske kaucije, pružanja besplatne sudske pomoći, kao i razmjene informacija o promjenama u pravu država ugovornica. ${ }^{77}$ Posebnu kategoriju predstavljaju sve brojniji ugovori o unaprjeđenju i zaštiti investicija, koji sadrže norme o pravima osoba iz jedne države ugovornice koje ulažu kapital u drugoj državi ugovornici, zaštiti od eksproprijacije i pravu na pravičnu naknadu u slučaju eksproprijacije, zatim, norme o rješavanju sporova koji proistječu iz stranih ulaganja i sl. ${ }^{78}$

Dvostrani međunarodni ugovori koji su danas na snazi u Republici Srbiji različitog su porijekla. Dio njih zaključila je država Srbija, dok je veći broj naslijedila od Državne zajednice Srbija i Crna Gora, koja je, opet, većinu ugovora naslijedila od SR Jugoslavije, odnosno ranije SFR Jugoslavije. Naime, u skladu s Polaznim osnovama za preuređenje odnosa Srbije i Crne Gore ("Beogradski sporazum") od 2006. godine i člankom 60. Ustavne povelje Državne zajednice Srbija i Crna Gora, ${ }^{79}$ Republika Srbija je postala pravni sljednik Državne zajednice Srbija i Crna Gora i u cijelosti naslijedila njezin međunarodnopravni subjektivitet i međunarodne dokumente.

S tim u vezi, treba napomenuti da je danas nesporan status dvostranih ugovora koje je zaključila sama Srbija, kao i onih naslijeđenih koje je zaključila SR Jugoslavija, odnosno Državna

74 Na primjer, Konvencija između Socijalističke Federativne Republike Jugoslavije i Republike Francuske o nadležnosti i o zakonu koji se primjenjuje u području osobnog i obiteljskog prava, Službeni list SFRJ, broj 55/1972.

75 Na primjer, Ugovor između Socijalističke Federativne Republike Jugoslavije i Narodne Republike Mađarske o uzajamnom pravnom saobraćaju, Službeni list SFRJ, Međunarodni ugovori i drugi sporazumi, broj 3/1968; izmene i dopune, Službeni list SFRJ, Međunarodni ugovori, broj 1/1987.

76 Npr. Ugovor o regulisanju pravnih odnosa u građanskim, porodičnim i krivičnim stvarima između SFR Jugoslavije i Čehoslovačke SR, Službeni list SFRJ, Dodatak, broj 13/1964.

77 Npr. Ugovor o uzajamnoj pravnoj pomoći između FNR Jugoslavije i NR Bugarske, Službeni list FNRJ; Dodatak, broj 1/1957.

78 Primjerice, Sporazum između Savezne Vlade SR Jugoslavije i Vlade Republike Poljske o uzajamnom podsticanju i zaštiti ulaganja, Službeni list SRJ, Međunarodni ugovori, broj 6/1996. 
zajednica Srbija i Crna Gora. Međutim, kada su posrijedi naslijeđeni dvostrani ugovori SFRJ, ${ }^{80}$ treba za svaki ugovor prije njegove primjene provjeriti kod Ministarstva spoljnih poslova je li regulirano pitanje nastavka važenja danog ugovora i poslije prestanka SFRJ. Riječ je o tome da oni nisu automatski nastavili vrijediti u novoj državnoj tvorevini ${ }^{81}$ i da je zato sa svakom državom ugovornicom bilo potrebno zaključiti poseban sporazum o sukcesiji ${ }^{82}$ (odnosno konsolidaciji ugovornog stanja) ${ }^{83}$ ili razmjenom nota ${ }^{84}$ urediti pitanje sukcesije dvostranih ugovora.

Ovi posebni sporazumi o sukcesiji su zaključeni, odnosno razmjena nota izvršena s određenim brojem država (ali ne sa svim!). Osim toga, u pojedinim posebnim sporazumima izostavljeni su određeni (uglavnom stariji) dvostrani ugovori. Otuda je, zbog oba razloga, korisna provjera važenja konkretnog "dvostranog ugovora SFRJ” na mrežnim stranicama Ministarstva spoljnih poslova.

Ono na što je naročito važno ovdje ukazati jest da je pojedine dvostrane ugovore o pravnoj pomoći u građanskim stvarima potrebno revidirati jer su rješenja u njima zastarjela ili su obuhvaćena odredbama kasnijih višestranih konvencija čije su članice i Srbija i odnosna strana država. Posebno je osjetljiva situacija u vezi s tim s državama članicama EU-a, s kojima imamo dvostrane međunarodne ugovore o pravnoj pomoći u građanskim stvarima, zaključene prije njihova stupanja u članstvo ove organizacije. U tom smislu, indikativna je inicijativa Republike Slovačke od 6. prosinca 2012. godine da se izmjeni postojeći dvostrani Ugovor o regulisanju pravnih odnosa u građanskim, porodičnim i krivičnim stvarima zaključen 1964. godine između SFR Jugoslavije i Čehoslovačke, koji je danas na snazi u odnosima naše zemlje i Slovačke (i Češke, također). ${ }^{85}$ Razlog je, kako se navodi u pismu slovačkog Ministarstva pravde, što "Republika Slovačka, kao članica Evropske Unije, ima dužnost koja proističe iz člana 351 Ugovora o funkcionisanju Evropske Unije da svoje obaveze prema trećim zemljama uredi u skladu sa njenim obavezama koje proističu iz njenog članstva u EU”. Kako se još navodi u pismu, odnosni Ugovor je "u konfliktu sa pravom EU, a posebno u pitanjima međunarodne nadležnosti i merodavnog prava (sukob zako-

$80 \quad$ Izraz "dvostrani ugovori SFRJ" odnosi se na sve dvostrane ugovore koji su bili na snazi u trenutku disolucije SFRJ. Oni obuhvaćaju kako ugovore koje je zaključila sama SFRJ, tako i ugovore koje je ona naslijedila od ranijih država (FNRJ, Kraljevina Jugoslavija, Kraljevina SHS).

81 Vidjeti detaljnije o problemu važenja međunarodnih izvora posle prestanka SFRJ i stavu Badinterove komisije, Stanivuković et al., op. cit. str. 71.

82 Ove sporazume Državna zajednica Srbija i Crna Gora zaključila je npr. s Danskom (Sporazum između Saveta Ministara Srbije i Crne Gore i Vlade Kraljevine Danske o sukcesiji u odnosu na ugovore zaključene između Socijalističke Federativne Republike Jugoslavije i Kraljevine Danske, Službeni list SCG, Međunarodni ugovori, broj 3/2004), Egiptom (Sporazum između Saveta Ministara Srbije i Crne Gore i Vlade Arapske Republike Egipta o sukcesiji ugovora zaključenih između Socijalističke Federativne Republike Jugoslavije i Arapske Republike Egipta, Službeni list SCG, Međunarodni ugovori, broj 3/2006), Portugalom (Sporazum između Srbije i Crne Gore i Portugalske Republike o sukcesiji sporazuma koji su bili na snazi između Socijalističke Federativne Republike Jugoslavije i Portugalske Republike, Službeni list SCG, Međunarodni ugovori, broj 22/2004), Francuskom (Sporazum između Saveta Ministara Srbije i Crne Gore i Vlade Republike Francuske o sukcesiji bilateralnih ugovora zaključenih između Socijalističke Federativne Republike Jugoslavije i Francuske, Službeni list SCG, Međunarodni ugovori, broj 6/2003) i Španjolskom (Sporazum između Srbije i Crne Gore i Kraljevine Španije o sukcesiji bilateralnih sporazuma, Službeni list SCG, Međunarodni ugovori, broj 14/2005).

83 Ovaj Sporazum je nekadašnja Državna zajednica Srbija i Crna Gora zaključila s Belgijom (Sporazum o konsolidaciji ugovornog stanja između Saveta Ministara Srbije i Crne Gore i Vlade Kraljevine Belgije, Službeni list SCG, Međunarodni ugovori, broj 10/2005).

84 Sukcesija u vezi s dvostranim ugovorima SFRJ uređena je na ovaj način sa sljedećim državama: Austrija (1997), Grčka (1997), Iran (1997), Kanada (1997), DNR Koreja (1997), Meksiko (2002), Njemačka (2002), Norveška (2003), Poljska (1996), Slovačka (1996), Nizozemska (2002), Češka (2002), Švicarska (1998), Švedska (2003), Ujedinjena Kraljevina (1998). 
na).” Zbog toga, Ministarstvo pravde Republike Slovačke predlaže zaključivanje Protokola o postojećem Ugovoru s ciljem da joj se omogući da uredi svoje obveze u skladu s njezinim obvezama koje proistječu iz članstva u EU-u i konkretno, sugeriraju da se iz Dijela Dva postojećeg Ugovora isključe njegovi Odjeljci od 1. do 4. i izmjeni Odjeljak 6. Kao argument navodi se da zaključenje novog ugovora ne bi odgovaralo Republici Slovačkoj, kako zbog stava Europske komisije da ne ovlašćuje države članice da zaključuju bilateralne ugovore s trećim državama (posebno kada je riječ o priznanju i ovrsi stranih odluka), ${ }^{86}$ tako i zbog rizika za Republiku Slovačku od eventualne povrede obveza i odgovarajućih sankcija unutar EU-a jer je riječ o području koje se stalno razvija u okviru EU-a i nemoguće je procijeniti u kojem pravcu će se stvari kretati u budućnosti. Napokon, istaknuto je i da su Republika Srbija i Republika Slovačka ugovornice relevantnih haških konvencija o dostavljanju, izvođenju dokaza i slobodnom pristupu sudovima te da "nije logično da se u bilateralnom instrumentu razgovara o tim pitanjima" (odnosno, da i njih treba izostaviti u novoj verziji Ugovora izmijenjene predloženim Protokolom). ${ }^{87}$

Nije teško pretpostaviti da će inicijativu istog (ili sličnoga sadržaja) Ministarstvu pravde Republike Srbije uputiti i druge države članice EU-a s kojima imamo dvostrane ugovore o pravnoj pomoći zaključene prije njihova stupanja u članstvo EU-a (još njih 13, uz Slovačku). ${ }^{88}$ Načelno, treba konstatirati da je u interesu Republike Srbije da prihvatimo takve inicijative i izmijenimo postojeće ugovore (osim onog dijela o priznanju i ovrsi stranih odluka, sve do završetka Judgment Projecta u okviru Haške konferencije za MPP i donošenja nove Konvencije o priznanju i ovrsi stranih sudskih odluka). ${ }^{89} \mathrm{Na}$ taj način, osuvremenili bismo te ugovore i uskladili ih s promjenama u našem sustavu MPP-a, ali isto tako, izbjegli bismo njihovo eventualno otkazivanje od strane države ugovornice članice EU-a. Naime, Republika Slovačka je benigno reagirala u svom pismu i navela da "u slučaju da Republika Srbija ne pokaže interes za reviziju postojećeg Ugovora

86 Treba napomenuti da je situacija drukčija u vezi s određenim pitanjima obiteljskog prava. Vidjeti Uredba Vijeća (EZ) broj 664/2009 o uvođenju postupka za pregovaranje i zaključivanje sporazuma između država članica i trećih zemalja o presudama, priznanjima i izvršenjima presuda i odluka u bračnim sporovima, sporovima o roditeljskoj odgovornosti i sporovima o obvezama uzdržavanja te važećem pravu u vezi sa sporovima o obvezama uzdržavanja, OJ L 200/46.

87 Vidjeti pobliže Đurđević, S., O potrebi izmene dvostranih ugovora o pravnoj pomoći u građanskim stvarima na snazi između Republike Srbije i država članica Evropske Unije, Zbornik radova Pravnog fakuteta u Nišu, god. LV, broj 74, 2016., str. 267.-287.

88 Na primjer, Austrija (Ugovor o uzajamnom pravnom saobraćaju između FNR Jugoslavije i Republike Austrije, Službeni list FNRJ, Dodatak, broj 8/1955 i Službeni list SFRJ, Međunarodni ugovori, broj 2/83), Belgija (Sporazum između Socijalističke Federativne Republike Jugoslavije i Kraljevine Belgije o pravnoj pomoći u građanskim i trgovačkim stvarima, Službeni list SFRJ, Dodatak, broj 7/1974), Bugarska (Ugovor između Federativne Narodne Republike Jugoslavije i Narodne Republike Bugarske o uzajamnoj pravnoj pomoći, Službeni list FNRJ, Dodatak, broj 1/1957), Grčka (Konvencija između Federativne Narodne Republike Jugoslavije i Kraljevine Grčke o uzajamnim pravnim odnosima, Službeni list FNRJ, Dodatak, broj 7/1960), Italija (Konvencija između Federativne Narodne Republike Jugoslavije i Italijanske Republike o uzajamnoj pravnoj pomoći u građanskim i upravnim stvarima, Službeni list FNRJ, Dodatak, broj 5/1963), Cipar (Ugovor između Socijalističke Federativne Republike Jugoslavije i Republike Kipar o pravnoj pomoći u građanskim i krivičnim stvarima, Službeni list SFRJ, Međunarodni ugovori, broj 2/1986), Mađarska (Ugovor o uzajamnom pravnom saobraćaju između SFR Jugoslavije i NR Mađarske, Službeni list SFRJ, Dodatak, broj 3/1968, broj 1/1987), Poljska (Ugovor između Federativne Narodne Republike Jugoslavije i Narodne Republike Poljske o pravnom saobraćaju u građanskim i krivičnim stvarima, Službeni list SFRJ, Dodatak, broj 5/1963), Rumunjska (Ugovor između Federativne Narodne Republike Jugoslavije i Rumunske Narodne Republike o pravnoj pomoći, Službeni list FNRJ, Dodatak, broj 8/1961).

89 Što je najavljeno za 22. Diplomatsku konferenciju, koja će se održati od 18. lipnja do 2. srpnja 2019. godine. Videti obavijest Haške konferencije za međunarodno privatno pravo o sazivanju 22. Diplomatske konferencije, URL= https://www.hcch.net/ en/projects/legislative-projects/judgments/22nd-diplomatic-session. Pristupljeno 25. veljače 2019. U međuvremenu, do objavljivanja ovog članka, Konvencija je usvojena, ali još je nijedna država nije ratificirala (potpisao ju je samo Urugvaj). No, nije riječ o oklijevanju nego o činjenici da obvezivanje Konvencijom zahtijeva duže pripreme i analize. Inače su za ratifikaciju zainteresirani EU, SAD, ali i Kina. Ako je spomenute države doista budu ratificirale, to će biti najuspješnija haška konvencija, sudeći prema značaju država koje su se obvezale i s obzirom na područje koje uređuje. Convention of 2 July 2019 on the Recognition and Enforcement of Foreign Judgments in Civil or Commercial Matters. 
putem predloženog Protokola, Ugovor iz 1964. godine će ostati na snazi između Republike Srbije i Slovačke, i Slovačka će nastaviti da ga primenjuje, u skladu sa pravilima međunarodnog javnog prava, sa prioritetom nad pravilima EU kako je i sada slučaj”. ${ }^{90}$ Međutim, već stavak 2. članka 307. Osnivačkog ugovora predviđa, u slučaju da prethodne obveze nisu kompatibilne s ovim Ugovorom, da države članice ili država u pitanju poduzimaju sve odgovarajuće korake radi otklanjanja utvrđene inkompatibilnosti. Prema tumačenju Europskog suda pravde, takvi koraci mogu čak podrazumijevati obvezu otkazivanja prethodno zaključenog ugovora. ${ }^{91}$ Takvo stanovište potvrđeno je u stavku 2. članka 351. UFEU-a, nametanjem državama članicama pozitivne obveze da otklone bilo kakvu inkompatibilnost između ugovora koje su ranije zaključile i sekundarnog zakonodavstva EU-a. ${ }^{92}$ Stoga su one u obvezi da što prije počnu pregovore s trećom državom, a ako to nije moguće, moraju otkazati takav ugovor.

Osim revizije ugovora o pravnoj pomoći u građanskim stvarima zaključenim s državama članicama EU-a, trebalo bi pristupiti reviziji ovih ugovora zaključenim i s trećim državama, ovog puta, na inicijativu Republike Srbije. ${ }^{93}$ Iako u ovim slučajevima ne postoji rizik otkazivanja ugovora od druge strane ugovornice (kao kada je riječ o državama članicama EU-a), izmjenom ovih (vremešnih) ugovora uskladili bismo njihova rješenja sa suvremenim dostignućima sadržanim kako u Nacrtu novog ZMPP-a Republike Srbije (2014), tako i u usporednom međunarodnom privatnom pravu.

\section{PITANJE PRIMJENE EUROPSKE KONVENCIJE O OBAVIJESTIMA O STRANOM PRAVU (1968) U SVJETLU NOVIH ZAKONSKIH ODREDABA O NAČINIMA UTVRĐIVANJA SADRŽAJA STRANOG PRAVA}

Europska konvencija o obavijestima o stranom pravu donesena je u okrilju Savjeta Europe u Londonu 7. lipnja 1968. godine. Stupila je na snagu u međunarodnom smislu 17. prosinca

90 Prema članku 234. Rimskog ugovora (naknadna numeracija 307, a u Lisabonskom ugovoru ovaj članak je numeriran kao članak 351. UFEU-a), ranije zaključeni međunarodni ugovori neće biti pogođeni kasnije zaključenim odredbama osnivačkog ugovora, što je u suglasnosti s člankom 34. Bečke konvencije o pravu ugovora, koji stipulira da ugovor ne može stvoriti prava ili obveze za treće subjekte. U skladu s tim, glavni cilj ovog članka prava EU-a je bio omogućiti državama članicama da poštuju svoje obveze prema trećim subjektima.

Case C-170/98, Commission v. Belgium, 14. 9. 1999, para. 42.

92 ESP je u pojedinim predmetima otišao korak dalje, ističući da obveza države da djeluje postoji čak i ako je riječ samo o potencijalnoj inkompatibilnosti, odnosno nesuglasnosti koja se još nije manifestirala. Case C-205/06 Commission of European Communities v. Republic of Austria, (2009), ECR 1-0 ii 301; Case 118/07, Commission of European Communities v. Republic of Finland (2009), ECR I-10889; Case 249/06 Commission of European Communities v. Republic of Sweden, (2009), ECR I-01335 (para. 42).

93 Na primjer, Alžir (Ugovor o pravnoj pomoći u građanskim i krivičnim stvarima između Socijalističke Federativne Republike Jugoslavije i Demokratske Narodne Republike Alžir, Službeni list SFRJ, Međunarodni ugovori, broj 2/1983 i 10/1984), Irak (Ugovor između Socijalističke Federativne Republike Jugoslavije i Republike Irak o pravnoj i sudskoj saradnji, Službeni list SFRJ, Međunarodni ugovori, broj 1/1987), Mongolija (Ugovor između Socijalističke Federativne Republike Jugoslavije i Mongolske Narodne Republike o pružanju pravne pomoći u građanskim, porodičnim i krivičnim stvarima, Službeni list SFRJ, Međunarodni ugovori, broj 7/1982), Rusija (Ugovor između Federativne Narodne Republike Jugoslavije i Saveza Sovjetskih Socijalističkih Republika o pravnoj pomoći u građanskim, porodičnim i krivičnim stvarima, Službeni list SFRJ, Međunarodni ugovori i drugi sporazumi, broj 5/1963), Turska (Ugovor između Republike Srbije i Republike Turske o uzajamnoj pravnoj pomoći u građanskim i trgovačkim stvarima, Službeni glasnik RS, Međunarodni ugovori, broj 15/2015). 
1969. godine. U našoj zemlji primjenjuje se od 1991. godine. ${ }^{94}$ Okuplja 45 država članica, ${ }^{95}$ od kojih neke, unatoč nazivu Konvencije, nisu europske države. ${ }^{96}$

Osnovna namjera tvoraca Konvencije bila je da se olakša utvrđivanje sadržaja stranog prava među državama članicama, ali tako da budu poštovana oba osnovna principa u ovoj pravnoj stvari - i princip pravne sigurnosti (jer se obavijesti dobivaju od kredibilnog tijela) i princip efikasnosti (jer su predviđeni relativno jednostavni mehanizmi komunikacije između nadležnih, središnjih tijela). Ipak, unatoč tim nastojanjima, dojam je da Konvencija nije u potpunosti ostvarila postavljene ciljeve. No, prije analize pojedinih pitanja, pogledajmo glavna rješenja ove relativno kratke Konvencije (ukupno 21 članak).

\subsection{OSNOVNA KONVENCIJSKA RJEŠENJA}

Strane ugovornice obvezuju se da jedna drugoj osiguravaju obavijesti o svom materijalnom i procesnom pravu u građanskim i trgovinskim stvarima, kao i o organizaciji pravosuđa. Dvije ili više država ugovornica mogu proširiti predmet ove Konvencije i na druge pravne oblasti, ali sporazum o tome moraju proslijediti glavnom tajniku Savjeta Europe.

Radi ostvarenja cilja Konvencije, svaka država ugovornica imenovat će "agenciju za primanje" koja prima zahtjeve stranih tijela za obavijesti o sadržaju svog prava i pruža odgovore na njih. Agencija za primanje mora biti ministarski resor ili neko drugo državno tijelo. Također, svaka država ugovornica imenovat će i "agenciju za slanje", koja prima zahtjeve za obavijesti $o$ stranom pravu od svojih pravosudnih tijela i prenosi ih stranoj nadležnoj "agenciji za primanje". Pritom je dopuštena mogućnost da država imenuje isto tijelo za obavljanje poslova "agencije za primanje" i "agencije za slanje". U Republici Srbiji to je Ministarstvo pravde i ono obavlja oba posla. Većina država je identično postupila, tako da osim malobrojnih iznimaka, ${ }^{97} \mathrm{u}$ pravilu je riječ o ministarstvima pravde država ugovornica kao nacionalnim tijelima za vezu u smislu ove Konvencije.

Što se tiče pitanja tko ima pravo podnijeti zahtjev za obavijestima, Konvencija predviđa da "zahtjev za obavijestima uvijek potječe od nekog pravosudnog tijela (judicial authority) čak i kad ga nije sačinilo to tijelo”. To praktično znači da će Ministarstvo pravde Republike Srbije

95 Članice ove Konvencije su sljedeće države: Albanija, Austrija, Azerbajdžan, Belgija, Bjelorusija, Bosna i Hercegovina, Bugarska, Cipar, Crna Gora, Češka, Danska, Estonija, Finska, Francuska, Grčka, Gruzija, Hrvatska, Island, Italija, Kostarika, Latvija, Lihtenštajn, Litva, Luksemburg, Makedonija, Malta, Mađarska, Maroko, Meksiko, Nizozemska, Norveška, Njemačka, Poljska, Portugal, Rumunjska, Rusija, Slovačka, Slovenija, Srbija, Španjolska, Švedska, Švicarska, Turska, Ukrajina i Velika Britanija.

96 Na primjer, članice ove Konvencije su Meksiko, Kostarika i Maroko. Osim toga, država ugovornica je i Bjelorusija koja također nije članica Savjeta Europe. Razlog tome je što članak 18. Konvencije (čiji je naslov "Pristupanje države koja nije članica Savjeta Europe”) predviđa da “ (1) Posle stupanja na snagu ove Konvencije, Komitet ministara Saveta Evrope može da pozove bilo koju državu koja nije članica da pristupi Konvenciji. (2) Takvo pristupanje izvršiće se deponovanjem kod generalnog sekretara Saveta Evrope instrumenta pristupanja, a Konvencija će stupiti na snagu u odnosu na tu državu tri meseca posle datuma njegovog deponovanja." Od država članica Savjeta Europe, članice ove Konvencije nisu: Andora, Armenija, Irska i San Marino.

97 Iznimke su uistinu malobrojne. Grčka je odredila Institut za međunarodno pravo u Ateni, Lihtenštajn - Apelacijski sud, Malta - Vrhovnog javnog pravobranitelja, a jedino Latvija ima dva različita tijela - Ministarstvo pravde je agencija za primanje, a javni tužitelj obavlja poslove agencije za slanje. 
prosljeđivati zahtjeve koje mu uputi postupajući sud. U Komentaru Konvencije ${ }^{98}$ navodi se da i stranke mogu inicirati podnošenje takvog zahtjeva, pri čemu se ne dovodi u pitanje odlučujuća uloga suda jer sud procjenjuje svrsishodnost podnošenja zahtjeva i odlučuje o potrebi njegova podnošenja. Uz to, Konvencija predviđa da je za podnošenje zahtjeva za obavijestima potrebno da bude ispunjen još jedan uvjet - zahtjev se može postaviti samo u slučajevima kada je postupak već pokrenut. Drugim riječima, ne može se tražiti obavijest o sadržaju stranog prava unaprijed, prije nego što je podignuta tužba ili je postupak pokrenut na neki drugi način.

U zahtjevu za obavijestima navest će se pravosudno tijelo od kojeg zahtjev potječe, kao i priroda slučaja. U njemu će se, što je preciznije moguće, navesti pitanja glede kojih se žele obavijesti u vezi s pravom države kojoj se zahtjev upućuje. Ako je riječ o državi sa složenim pravnim sustavom, sud Republike Srbije prethodno mora riješiti tzv. problem nejedinstvenog pravnog poretka (plurilegislativnih sistema) i da u svom zahtjevu točno naznači sadržaj kojeg pravnog područja unutar države sa složenim pravnim sustavom želi doznati (na primjer, kako glase norme prava Katalonije u vezi s nužnim dijelom, ako raspravlja o ostavini ostavitelja španjolskog državljanina). U zahtjevu se, također, mogu navesti činjenice potrebne kako za njegovo pravilno razumijevanje, tako i za formuliranje točnog i preciznog odgovora. Prema potrebi, mogu se priložiti kopije dokumenata da bi se razjasnio cilj zahtjeva.

Zahtjev za obavijesti prenijet će izravno "agenciji za primanje" zamoljene države "agencija za slanje” domaće države. Konkretno, u Srbiji to znači da će Ministarstvo pravde Republike Srbije prenijeti nadležnom inozemnom ministarstvu (ili nekom drugom tijelu, ako je on označen kao "agencija za primanje”) zahtjev za obavijesti o pravu te države koji mu je uputio sud Srbije.

Što se tiče pitanja tko će sastaviti odgovor i tako pružiti obavijesti o sadržaju svog prava, “agencija za primanje” ima tri mogućnosti. Najprije, to može učiniti ona sama. Zatim, ona može “zahtjev prenijeti nekom drugom službenom državnom tijelu koji će sastaviti odgovor”. Napokon, "u odgovarajućim slučajevima ili zbog potreba administrativne organizacije, (ona) može zahtjev prenijeti privatnom tijelu ili ovlaštenom odvjetniku koji će sastaviti odgovor". U Srbiji, odgovore, odnosno obavijesti o sadržaju srpskoga prava daje Ministarstvo pravde Republike Srbije, koje je, kako smo rekli, istodobno i “agencija za primanje”.

Cilj odgovora je davanje obavijesti o pravu zamoljene države "na objektivan i nepristran način". Odgovor treba sadržavati relevantne zakonske odredbe i relevantne sudske odluke. Ako je potrebno za pravilno obavješćivanje tijela koje je podnijelo zahtjev, bit će popraćen izvodima iz stručnih radova i pripremnih materijala, a također i komentarima i obrazloženjima.

Što se slanja obavijesti tiče, "agencija za primanje" zamoljene države uputit će ga "agenciji za slanje” države moliteljice. Praktično, to znači da će strano tijelo uputiti obavijesti Ministarstvu pravde Republike Srbije, koje će ju dalje dostaviti sudu od kojega je zahtjev potekao.

Konvencija predviđa da je "agencija za primanje" kojoj je poslan zahtjev za obavijesti dužna odgovoriti (sama ili uz pomoć drugih tijela, u smislu članka 6.), a da može odbiti postupiti prema zahtjevu, jedino ako slučaj u vezi s kojim je zahtjev podnesen utječe na njezine interese ili ako smatra da bi odgovor mogao ugroziti njezin suverenitet ili sigurnost.

98 Council of Europe, Explanatory Report to the European Convention on Information on Foreign Law, 1968. https://rm.coe. int/CoERMPublicCommonSearchServices/DisplayDCTMContent?documentId=09000016800c92f3. Pristupljeno 12. listopada 2018. 
Odgovor na zahtjev za obavijesti bit će upućen što je moguće brže. Međutim, ako priprema odgovora zahtijeva dulje vrijeme, "agencija za primanje" o tome će obavijestiti strano tijelo koje šalje zahtjev i, ako je moguće, istodobno naznačiti vjerojatni datum do kojeg će odgovor biti proslijeđen.

Ako je "agenciji za primanje ili tijelu ili osobi kojima je naloženo da odgovore nešto nejasno u samom zahtjevu, mogu zatražiti od tijela koje je uputilo zahtjev da osigura dopunske obavijesti nužne za sastavljanje odgovora.

Zahtjev za obavijesti i prilozi uz njega bit će sastavljeni na jeziku ili jednom od jezika zamoljene države ili će biti popraćeni prijevodom na taj jezik. Odgovor će biti sastavljen na jeziku zamoljene države. Međutim, dvije ili više država ugovornica mogu se dogovoriti da u međusobnim odnosima primjenjuju drukčije rješenje.

Kada je riječ o troškovima, pravilo je da odgovor ne podrazumijeva plaćanje bilo kakvih naknada ili troškova. Jedina iznimka predviđena je u slučaju da "agencija za primanje" prenese zahtjev privatnom tijelu ili ovlaštenom odvjetniku. Tada, ako je vjerojatno da će njihovo angažiranje podrazumijevati određene troškove, "agencija za primanje”, prije nego što obavi prijenos, šalje dopis tijelu od kojega zahtjev potječe u kojemu: 1. Naznačuje privatno tijelo ili odvjetnika kome će zahtjev biti prenesen; 2. Obavještava spomenuto tijelo što je moguće preciznije o vjerojatnim troškovima, i 3. Traži njegovu suglasnost za prijenos. Ako tijelo dâ suglasnost, troškove će snositi njegova država (država od koje zahtjev potječe). No, i ovdje, dvije ili više država ugovornica mogu se dogovoriti da u međusobnim odnosima primjenjuju drukčije rješenje. Obavijesti dane u odgovoru neće obvezivati pravosudno tijelo države iz koje je zahtjev potekao (članak 8.). Ova odredba je kritično mjesto u Konvenciji i stvara određene probleme u praksi. O njima će biti više riječi u sljedećim odjeljcima.

\subsection{PRIMJENA KONVENCIJE U SUDSKOJ PRAKSI}

U praksi sudova Republike Srbije nalazimo desetak objavljenih odluka koje se tiču utvrđivanja sadržaja stranog prava, a nekoliko njih odnose se na Europsku konvenciju i primjenu njezinih odredaba. Što se tiče odluka u kojima se Konvencija ne spominje, iako je riječ o odnosima s državama članicama, može se pretpostaviti da su se sudovi prema inerciji pozivali na članak 13. Zakona o rešavanju sukoba zakona, utoliko prije što je u oba slučaja (i prema Konvenciji i prema članku 13. ZRSZ-a) Ministarstvo pravde nadležno tijelo kojem se treba obratiti za obavijesti o sadržaju stranog prava. ${ }^{99}$ Ipak, s obzirom na stav da se u presudi mora navesti način na koji je utvrđen sadržaj stranog prava, ${ }^{100}$ dakle, i činjenica od kojeg tijela je pribavljena obavijest, dojam je da je trebalo primijeniti konvencijske odredbe. Ovo zbog toga što se u nekoliko odluka, u kojima se poziva na Europsku konvenciju, upravo insistira da oba-

99 Tako, na primjer u rješenju Apelacionog suda u Beogradu, Gž 7185/2011 od 13. ožujka 2013. godine; rješenju Višeg trgovinskog suda, Pž. 4631/2009 od 4. lipnja 2009. godine; rješenju Višeg trgovinskog suda Iž. 2535/2006 od 26. ožujka 2007. godine; rješenje Višeg trgovinskog suda Pž. 3471/2004 od 15. rujna 2004. godine. Prema paragraf.net, sudska praksa uz članak 13. ZRSZ-a.

100 "Kada (...) sud primenjuje strano pravo, dužan je da navede način na koji je došao do saznanja o sadržini stranog prava (u smislu člana 13. ZRSZ)." Presuda Privrednog apelacionog suda, Pž. 847/2011(2) od 28. prosinca 2011. godine. Prema paragraf.net, sudska praksa uz članak 13- ZRSZ-a. 
vijest o sadržaju stranog prava bude izdana u obliku javne isprave od strane nadležnog tijela (koje je odnosna država imenovala). Tako, na primjer, navodi se da se "Javnom ispravom može smatrati samo ona koju je izdao organ koji je za to nadležan u odgovarajućem postupku, te se stoga ne može prihvatiti kao javna isprava o dokazivanju sadržaja stranog prava, prevod overen od strane sudskog tumača, obzirom da nije zasnovan na tekstu stranog prava u formi javne isprave, izdate od strane kvalifikovanog organa, shodno Evropskoj konvenciji o obaveštenjima o stranom pravu." ${ }^{01}$ Sličnu argumentaciju nalazimo i u drugim odlukama ovog suda. ${ }^{102}$ Međutim, već ovdje nastaju prvi problemi jer može biti riječi o odnosu s državom s kojom imamo zaključen dvostrani ugovor u kojem je predviđeno da ministarstva inozemnih poslova jedno drugom daju obavijesti o stranom pravu, dok je ta strana država u Europskoj konvenciji označila drugo tijelo kao "agenciju za primanje" i "agenciju za slanje” u smislu Europske konvencije. Takva je situacija, na primjer, u odnosima Republike Srbije s Grčkom. Prema članku 31. (“Obaveštavanje o pravnim propisima”) Konvencije o uzajamnim pravnim odnosima između FNRJ i Kraljevine Grčke (1959), ${ }_{103}$ "Državni sekretarijat za inostrane poslove FNRJ i Ministarstvo inostranih poslova Kraljevine Grčke davaće jedan drugome, na zahtev, tekst propisa koji su na snazi na području njihove države, a po potrebi i obaveštenja o određenim pravnim pitanjima." S druge strane, Grčka je u smislu Ezropske konvencije odredila Institut za međunarodno pravo u Ateni kao "agenciju za slanje”. Teško je povjerovati u rigidnu dosljednost naših sudova koji bi inzistirali na javnoj ispravi izdanoj od nadležnog tijela prema Europskoj konvenciji (Instituta za međunarodno pravo), ne prihvaćajući pritom javnu ispravu izdanu od Ministarstva inozemnih poslova Grčke. U ovom slučaju, dojam je, javna isprava izdana bilo od jednog ili drugog tijela može se smatrati kredibilnom javnom ispravom o sadržaju grčkog prava.

\subsection{ODNOS KONVENCIJSKOG RJEŠENJA PREMA NOVIM NAČINIMA UTVRĐIVANJA SADRŽAJA STRANOG PRAVA}

Striktno inzistiranje sudova na primjeni Europske konvencije glede načina utvrđivanja sadržaja stranog prava čini se nepotrebnim, utoliko što njezin članak 8. ("Dejstva odgovora”) jasno predviđa da "Obaveštenja data u odgovoru neće obavezivati pravosudni organ iz kog je zahtev potekao." Sudac i u ovom slučaju, dakle, ostaje gospodar odluke o sadržaju stranog prava, i nevezan dobivenim obavijestima preko Europske konvencije može pokušati sadržaj stranog prava doznati i na drugi način. Ali, pitanje je - na koji način? Članak 13. ZRSZ-a očigledno mu ostavlja vrlo malo prostora, odnosno samo još jednu mogućnost, da stranka u čijem je to interesu podnese javnu ispravu o sadržaju stranog prava. U tom smislu, konvencijsko rješenje može zadržavati praktični značaj.

Međutim, stvari se mijenjaju u suvremenom međunarodnom privatnom pravu. Tako, na primer, stavci 3. i 4. članka 8. novog hrvatskog ZMPP-a (koji će stupiti na snagu 29. siječnja 2019. godine) predviđaju da "Sud ili drugo tijelo Republike Hrvatske može obavijest o sadržaju

101 Rješenje Višeg trgovinskog suda, Pž. 7092/2008 od 17. srpnja 2009. godine. Prema paragraf.net, sudska praksa uz članak 13. ZRSZ-a.

102 Rješenje Višeg trgovinskog suda, Iž. 2714/2007 od 23. prosinca 2008. godine. Prema paragraf.net, sudska praksa uz članak 13. ZRSZ-a.

103 Službeni list FNRJ, Dodatak, broj 7/1960, a stupila je na snagu 31. ožujka 1960. godine. 
prava strane države zatražiti od Ministarstva nadležnog za poslove pravosuđa ili nekog drugog tijela, kao i vještaka ili specijaliziranih ustanova" (stavak 3.), odnosno da "Stranke mogu podnositi javne ili privatne isprave o sadržaju prava strane države" (stavak 4.). Nacrt novog ZMPP-a Republike Srbije (2014) ${ }^{104}$ u stavcima 2.-4. članka 40. također predviđa nove načine utvrđivanja sadržaja stranog prava, odnosno rješenja vrlo slična onim iz hrvatskog ZMPP-a. U takvoj situaciji kada uistinu postoji više načina za utvrđivanje sadržaja stranog prava (mogućnost ekspertskog utvrđivanja sadržaja stranog prava, mogućnost obraćanja i drugom tijelu osim Ministarstva pravde, mogućnost podnošenja i privatne isprave o sadržaju stranog prava), rješenje iz Europske konvencije doima se nekako anakronično. Sudac sada može i u okviru svoje države doznati sadržaj stranog prava (bez potrebe za sudjelovanjem stranih tijela i brigom za skraćivanjem načina komunikacije) na također siguran, ali prije svega brži način. Zbog toga se postavlja pitanje daljnje sudbine Europske konvencije. Ona kao međunarodni izvor nesumnjivo ima primat u odnosu na zakonska rješenja. Međutim, očigledno je da je taj primat samo nominalan i u ovom slučaju nekoristan. Uz njezin važan "nedostatak" iz članka 8. (da obavijest ne obvezuje sud), spomenuta zakonska rješenja mnogo su raznovrsnija, praktičnija, jednostavno - bolja. Otuda se čini da će rješenje iz Europske konvencije u praksi biti potisnuto novim rješenjima iz ZMPP-a koja omogućavaju sudcu da izabere način utvrđivanja sadržaja stranog prava koji u konkretnom slučaju smatra najprikladnijim. ${ }^{105}$ Drugim riječima, bez osjećaja pretjerivanja, usudili bismo se reći da će s vremenom Europska konvencija biti potisnuta u zaborav.

\section{ZAKLJUČAK}

Povećanje broja međunarodnih ugovora, bez obzira na to je li riječ o višestranim ili dvostranim, nužno dovodi do stvaranja višestrukih kolosijeka u primjeni normi o međunarodnoj nadležnosti, mjerodavnom pravu ili priznanju i izvršenju stranih sudskih odluka. Iz kuta države članice Unije, ionako složeno pitanje dodatno dobiva na težini budući da su ovi kolosijeci sve više ispresijecani uredbama i direktivama kojima se regionalizira međunarodno privatno pravo za potrebe EU-a. U svakom slučaju, bilo da je riječ o državi koja, kao Republika Srbija, ima status kandidata za članstvo u Uniji, ili državi koja je, poput Republike Hrvatske, već njezin član, problem odabira pravog kolosijeka podrazumijeva solidno znanje i vještinu sudca ili drugog pravnog praktičara. Iako je katkada teško snaći se u labirintu međunarodnih ugovora, njihov je značaj u materiji međunarodnog privatnog prava nesporan, imajući u vidu da se upravo njima premošćuju razlike koje postoje između nacionalnih sustava ove grane prava. Da bi primjena međunarodnog ugovora doprinijela ostvarivanju opravdanih očekivanja stranaka i međunarodne suradnje (kao ciljeva međunarodnog privatnog prava), uz dobro poznavanja pitanja njihova stupanja na snagu i međusobne hijerarhije, jednako je važno nastojati da se pitanja međunarodnog privatnog prava uređena dvostranim ugovorima u razumnoj mjeri re-

104 Nacrt novog Zakona o međunarodnom privatnom pravu RepublikeSrbije (2014).https://www.mpravde.gov.rs/obavestenje/6274/ konacna-verzija-nacrta-zakona-o-medjunarodnom-privatnom-pravu-.php. Pristupljeno 10. studenoga 2018.

105 Problem odnosa međunarodnog ugovora i zakona koji je poslije donesen, a koji drukčije uređuje relevantnu materiju razmatran je i u starijoj jugoslavenskoj teoriji međunarodnog privatnog prava, vidjeti Eisner, B., Međunarodno privatno pravo, I. svezak, Zagreb, 1953., str. 41.-42. 
duciraju. To se može postići tako što bi se u dvostranim ugovorima ostavila samo ona rješenja koja nisu u međuvremenu regulirana suvremenijim višestranim konvencijama koje također obvezuju konkretne države. Konačno, treba istaknuti da postoje i slučajevi kada su nova zakonska rješenja efikasnija u odnosu na starija konvencijska, te pitanje pravog kolosijeka tada može postati još delikatnije, baš kao i ostvarenje cilja višestrane konvencije u takvoj situaciji.

\section{LITERATURA}

1. Avramov, S.; Kreća, M., Međunarodno javno pravo, Beograd, 2009.

2. Dika, M.; Knežević, G.; Stojanović, S., Komentar Zakona o međunarodnom privatnom i procesnom pravu, Nomos, Beograd, 1991.

3. Đurđević, S., O potrebi izmene dvostranih ugovora o pravnoj pomoći u građanskim stvarima na snazi između Republike Srbije i država članica Evropske Unije, Zbornik radova Pravnog fakulteta u Nišu, god. LV, br. 74, 2016., str. 267.-287.

4. Eisner, B., Međunarodno privatno pravo, I. svezak, Zagreb, 1953.

5. Etinski, R., Đajić, S., Tubić, B., Međunarodno javno pravo, Pravni fakultet, Centar za izdavačku delatnost, Novi Sad, 2017.

6. Jezdić, M., Međunarodno privatno pravo I, Naučna knjiga, Beograd, 1980.

7. Marjanović, S., Međunarodno ostvarivanje izdržavanja članova porodice - birajući između Konvencije UN (1956) i Haške konvencije (2007), Zbornik radova Pravnog fakulteta Univerzitetat u Nišu, br. 78, 2018., str. 235.-254.

8. Pravosudne multilateralne konvencije, Projuris, Beograd, 2005.

9. Pravosudne bilateralne konvencije, Projuris, Beograd, 2005.

10. Stanivuković, M.; Živković, M., Međunarodno privatno pravo: opšti deo, Službeni glasnik, Beograd, 2015.

11. Todorović, V., Međunarodna pravna pomoć: 78 multilateralnih međunarodnih konvencija, Službeni glasnik, Beograd, 2003.

12. Todorović, V., Međunarodna pravna pomoć: bilateralne konvencije, Službeni glasnik, Beograd, 1999.

13. Todorović. V., Pravosudna međunarodna pomoć, Projuris, Beograd, 2005.

14. Varadi, T.; Bordaš, B.; Knežević, G.; Pavić, V., Međunarodno privatno pravo, Službeni glasnik, Beograd, 2016.

15. von Overbeck, A. E., L'application par le juge interne des conventions de droit international privé, Collected Courses of the Hague Academy of International Law, Hague Academy of International Law, The Hague, Vol. 132, 1971.

16. Živković, M., Međunarodno privatno pravo - neprijatna nepoznanica naših sudova?, Pravni život, Savez udruženja pravnika Srbije, Beograd, br. 7-8, 1992., str. 1083.-1107.

17. Živković, M., Tumačenje članova 2, 4. i 7. priloga "G" sporazuma o pitanjima sukcesije u praksi naših sudova i drugih organa, u: Liber Amicorum: Dobrosav Mitrović, Spoljnotrgovinska arbitraža pri Privrednoj komori Srbije, Beograd, 2007., str. 691.-721. 


\section{POPIS PROPISA, AKATA I SUDSKIH ODLUKA}

1. Bečka konvencija o ugovornom pravu, Službeni list SFRJ, Međunarodni ugovori i drugi sporazumi, broj 30/1972.

2. Case C-170/98, Commission v. Belgium, 14. rujna 1999.

3. Case C-205/06 Commission of European Communities v. Republic of Austria, (2009), ECR 1-0 ii 301.

4. Case 118/07, Commission of European Communities v. Republic of Finland (2009), ECR I-10889.

5. Case 249/06 Commission of European Communities v. Republic of Sweden, (2009), ECR I-01335.

6. Haška konvencija o građanskom postupku, Službeni list FNRJ, Međunarodni ugovori i drugi sporazumi, broj 6/1962.

7. Haška konvencija o olakšanju međunarodnog pristupa sudovima, Službeni list SFRJ, Međunarodni ugovori, broj 4/1988.

8. Haška konvencija o građanskopravnim aspektima međunarodne otmice djece, Službeni list SFRJ, Međunarodni ugovori, broj 7/1991.

9. Haška konvencija o ukidanju zahtjeva legalizacije stranih javnih isprava, Službeni list FNRJ, Međunarodni ugovori i drugi sporazumi, broj 10/1962.

10. Haška Konvencija o sukobima zakona u pogledu forme testamentarnih odredaba, Službeni list FNRJ, Međunarodni ugovori i drugi sporazumi, broj 10/1962.

11. Haška konvencija o zakonu koji se primenjuje u slučajevima odgovornosti proizvođača za svoje proizvode, Službeni list SFRJ, Međunarodni ugovori, broj 8/1977.

12. Haška konvencija o nadležnosti, merodavnom pravu, priznanju i izvršenju odluka i saradnji u materiji roditeljske odgovornosti i mera za zaštitu dece, Službeni glasnik RS, Međunarodni ugovori, broj 20/2015.

13. Haška konvencija o pribavljanju u inostranstvu dokaza u građanskim i trgovačkim stvarima, Službeni glasnik RS, Međunarodni ugovori, br. 1/2010 i 13/2013.

14. Haška konvencija o zakonu koji se primenjuje na saobraćajne nezgode, Službeni list SFRJ, Međunarodni ugovori i drugi sporazumi, broj 26/1976.

15. Haška konvencija o nadležnosti, merodavnom pravu, priznanju i izvršenju i saradnji u materiji roditeljske odgovornosti i mera za zaštitu dece, Službeni glasnik RS, Međunarodni ugovori, broj 20/2015.

16. Konvencija o zastarelosti potraživanja u oblasti međunarodne kupoprodaje robe, Službeni list SFRJ, Međunarodni ugovori, broj 5/1978.

17. Konvencija o zaštiti dece i saradnji prilikom međunarodnog usvojenja, Službeni glasnik RS, Međunarodni ugovori, broj 12/2013.

18. Konvencija UN o međunarodnoj prodaji robe, Službeni list SFRJ, Međunarodni ugovori, broj 10-1/1984.

19. Konvencija između SFRJ i Republike Francuske o nadležnosti i o zakonu koji se primenjuje u oblasti ličnog i porodičnog prava, Službeni list SFRJ, broj 55/1972.

20. Konvencija između SFRJ i Kraljevine Belgije o uzajamnom priznanju i izvršenju sudskih odluka o izdržavanju, Službeni list SFRJ, Međunarodni ugovori i drugi sporazumi, broj 45/1976.

21. Konvencija o ostvarivanju alimentacionih zahteva u inostranstvu, Službeni list FNRJ, Međunarodni ugovori i drugi sporazumi, broj 2/1960. 
22. Konvencija između Federativne Narodne Republike Jugoslavije i Kraljevine Grčke o uzajamnim pravnim odnosima, Službeni list FNRJ, Dodatak, broj 7/1960.

23. Konvencija između Federativne Narodne Republike Jugoslavije i Italijanske Republike o uzajamnoj pravnoj pomoći u građanskim i upravnim stvarima, Službeni list FNRJ, Dodatak, broj 5/1963.

24. Konvencija između Socijalističke Federativne Republike Jugoslavije i Kraljevine Belgije o priznanju i izvršenju odluka o izdržavanju, Službeni list SFRJ, Međunarodni ugovori i drugi sporazumi, broj 45/1976.

25. Konvencija o obaveštenjima o stranom pravu, Službeni list SFRJ, Međunarodni ugovori, broj 7/1991.

26. Konvencija o uzajamnim pravnim odnosima između FNRJ i Kraljevine Grčke, Službeni list FNRJ, Dodatak, broj 7/1960.

27. Obaveštenje o datumu stupanja na snagu Konvencije o nadležnosti, merodavnom pravu, priznanju i izvršenju odluka i saradnji u materiji roditeljske odgovornosti i mera za zaštitu dece, Službeni glasnik RS, Međunarodni ugovori, broj 2/2016.

28. Presuda Privrednog apelacionog suda, Pž. 847/2011(2) od 28. prosinca 2011.

29. Rešenje Apelacionog suda u Beogradu, Gž 7185/2011 od 13. ožujka 2013.

30. Rešenje Višeg trgovinskog suda, Pž. 4631/2009 od 4. lipnja 2009.

31. Rešenje Višeg trgovinskog suda Iž. 2535/2006 od 26. ožujka 2007.

32. Rešenje Višeg trgovinskog suda Pž. 3471/2004 od 15. rujna 2004.

33. Rešenje Višeg trgovinskog suda, Pž. 7092/2008 od 17. srpnja 2009.

34. Rešenje Višeg trgovinskog suda, Iž. 2714/2007 od 23. prosinca 2008.

35. Sporazum o pitanjima sukcesije bivše SFRJ, Službeni list SRJ, Međunarodni ugovori, broj 6/2002.

36. Sporazum između Saveta Ministara Srbije i Crne Gore i Vlade Kraljevine Danske o sukcesiji u odnosu na ugovore zaključene između Socijalističke Federativne Republike Jugoslavije i Kraljevine Danske, Službeni list SCG, Međunarodni ugovori, broj 3/2004.

37. Sporazum između Saveta Ministara Srbije i Crne Gore i Vlade Arapske Republike Egipta o sukcesiji ugovora zaključenih između Socijalističke Federativne Republike Jugoslavije i Arapske Republike Egipta, Službeni list SCG, Međunarodni ugovori, broj 3/2006.

38. Sporazum između Srbije i Crne Gore i Portugalske Republike o sukcesiji sporazuma koji su bili na snazi između Socijalističke Federativne Republike Jugoslavije i Portugalske Republike, Službeni list SCG, Međunarodni ugovori, broj 22/2004.

39. Sporazum između Saveta Ministara Srbije i Crne Gore i Vlade Republike Francuske o sukcesiji bilateralnih ugovora zaključenih između Socijalističke Federativne Republike Jugoslavije i Francuske, Službeni list SCG, Međunarodni ugovori, broj 6/2003.

40. Sporazum između Srbije i Crne Gore i Kraljevine Španije o sukcesiji bilateralnih sporazuma, Službeni list SCG, Međunarodni ugovori, broj 14/2005.

41. Sporazum o konsolidaciji ugovornog stanja između Saveta Ministara Srbije i Crne Gore i Vlade Kraljevine Belgije, Službeni list SCG, Međunarodni ugovori, broj 10/2005.

42. Sporazum između Savezne Vlade SR Jugoslavije i Vlade Republike Poljske o uzajamnom podsticanju i zaštiti ulaganja, Službeni list SRJ, Međunarodni ugovori, broj 6/1996.

43. Sporazum između Socijalističke Federativne Republike Jugoslavije i Kraljevine Belgije o pravnoj pomoći u građanskim i trgovačkim stvarima, Službeni list SFRJ, Dodatak, broj 7/1974.

44. Sporazum između Jugoslavije i Austrije o uzajamnom priznavanju i izvršenju odluka o izdržavanju, Službeni list SFRJ, Dodatak, broj 2/1963. 
45. Ugovor između Socijalističke Federativne Republike Jugoslavije i Čehoslovačke Socijalističke Republike o regulisanju pravnih odnosa u građanskim, porodičnim i krivičnim stvarima, Službeni list SFRJ, Dodatak, broj 13/1964.

46. Ugovor između Federativne Narodne Republike Jugoslavije i Narodne Republike Bugarske o uzajamnoj pravnoj pomoći, Službeni list FNRJ, Dodatak, broj 1/1957.

47. Ugovor o uzajamnom pravnom saobraćaju između FNR Jugoslavije i Republike Austrije, Službeni list FNRJ, Dodatak, br. 8/1955 i Službeni list SFRJ, Međunarodni ugovori, br. 2/83.

48. Ugovor između Socijalističke Federativne Republike Jugoslavije i Republike Kipar o pravnoj pomoći u građanskim i krivičnim stvarima, Službeni list SFRJ, Međunarodni ugovori, br. 2/1986.

49. Ugovor o uzajamnom pravnom saobraćaju između SFR Jugoslavije i NR Mađarske, Službeni list SFRJ, Dodatak, br. 3/1968, br. 1/1987.

50. Ugovor između Federativne Narodne Republike Jugoslavije i Narodne Republike Poljske o pravnom saobraćaju u građanskim i krivičnim stvarima, Službeni list SFRJ, Dodatak, br. 5/1963.

51. Ugovor između Federativne Narodne Republike Jugoslavije i Rumunske Narodne Republike o pravnoj pomoći, Službeni list FNRJ, Dodatak, br. 8/1961.

52. Ugovor između Socijalističke Federativne Republike Jugoslavije i Republike Irak o pravnoj i sudskoj saradnji, Službeni list SFRJ, Međunarodni ugovori, br. 1/1987

53. Ugovor između Socijalističke Federativne Republike Jugoslavije i Mongolske Narodne Republike o pružanju pravne pomoći u građanskim, porodičnim i krivičnim stvarima, Službeni list SFRJ, Međunarodni ugovori, br. 7/1982.

54. Ugovor između Federativne Narodne Republike Jugoslavije i Saveza Sovjetskih Socijalističkih Republika o pravnoj pomoći u građanskim, porodičnim i krivičnim stvarima, Službeni list SFRJ, Međunarodni ugovori i drugi sporazumi, br. 5/1963.

55. Ugovor između Republike Srbije i Republike Turske o uzajamnoj pravnoj pomoći u građanskim i trgovačkim stvarima, Službeni glasnik RS, Međunarodni ugovori, br. 15/2015.

56. Ugovor o pravnoj pomoći u građanskim i krivičnim stvarima između Socijalističke Federativne Republike Jugoslavije i Demokratske Narodne Republike Alžir, Službeni list SFRJ, Međunarodni ugovori, br. 2/1983 i 10/1984.

57. Uredba Vijeća (EZ) br. 664/2009 o uvođenju postupka za pregovaranje i zaključivanje sporazuma između država članica i trećih zemalja o presudama, priznanjima i izvršenjima presuda i odluka u bračnim sporovima, sporovima o roditeljskoj odgovornosti i sporovima o obvezama uzdržavanja te važećem pravu u vezi sporova o obvezama uzdržavanja, OJ L 200/46.

58. Ustav Republike Srbije, Službeni glasnik RS, br. 98/2006.

59. Ustavna povelja Državne zajednice Srbija i Crna Gora, Službeni list SCG, br. 1/2003 i 26/2005.

60. Zakon o zaključivanju i izvršavanju međunarodnih ugovora, Službeni glasnik RS, br. 32/2013.

61. Zakon o rešavanju sukoba zakona sa propisima drugih zemalja, Službeni list SFRJ, br. 43/1982 i 72/1982 - ispr., Službeni list SRJ, broj 46/1996 i Službeni glasnik RS, broj 46/2006.

62. Zakon o Ustavnom sudu, Službeni glasnik RS, broj 109/2007. 


\section{MREŽNI IZVORI}

1. Convention of 5 October 1961 concerning the powers of authorities and the law applicable in respect of the protection of infants). URL=https://www.hcch.net/en/instruments/conventions/ full-text/?cid=39. Pristupljeno 10. listopada 2018.

2. Convention of 2 October 1973 Concerning the International Administration of the Estates of Deceased Persons. URL=https://www.hcch.net/en/instruments/conventions/full-text/?cid=83. Pristupljeno 12. studenoga 2018.

3. Convention of 1 February 1971 on the Recognition and Enforcement of Foreign Judgments in Civil and Commercial Matters. URL=https://www.hcch.net/en/ instruments/conventions/full-text/?cid=78. Pristupljeno 12. studenoga 2018

4. Council of Europe, Explanatory Report to the European Convention on Information on Foreign Law, 1968.URL=https://rm.coe.int/CoERMPublicCommonSearchServices/DisplayDCTMContent?documentId=09000016800c92f3. Pristupljeno 12. listopada 2018.

5. Hague Convention of 23 November 2007 on the International Recovery of Child Support and Other Forms of Family Maintenance. URL=https://assets.hcch.net/docs/14e71887-0090-47a3-9c49d438eb601b47.pdf. Pristupljeno 12. listopada 2018.

6. Konvencija UN o imunitetu države i njenoj imovini (United Nations Convention on Jurisdictional Immunities of States and Their Property), 2004. URL=http://legal. un.org/ilc/texts/instruments/ english/conventions/4-1-2004.pdf. Pristupljeno 12. listopada 2018.

7. Ministarstvo pravde Republike Srbije, Bilateralni i multilateralni međunarodni ugovori u građanskim stvarima. URL=https://www.mpravde.gov.rs/tekst/47/medjunarodni-ugovori-u-gradjanskim-stvarima.php. Pristupljeno 25. veljače 2019.

8. Ministarstvo spoljnih poslova Republike Srbije, Bilateralni odnosi sa stranim državama. URL= http://www.mfa.gov.rs/sr/index.php/spoljna-politika/bilateralni-odnosi?lang=cyr. Pristupljeno 25. veljače 2019.

9. Nacrt novog Zakona o međunarodnom privatnom pravu Republike Srbije (2014). URL=https:// www.mpravde.gov.rs/obavestenje/6274/konacna-verzija-nacrta-zakona-o-medjunarodnom-privatnom-pravu-.php. Pristupljeno 10. studenoga 2018.

10. Obaveštenje Haške konferencije za međunarodno privatno pravo o sazivanju 22. Diplomatske konferencije, URL= https://www.hcch.net/en/projects/legislative-projects/judgments/22nd-diplo matic-session. Pristupljeno 25. veljače 2019.

11. URL=https://www.paragraf.rs/. Pristupljeno 25. veljače 2019. 
Mirko Živković*

Sanja Marjanović**

\section{SOME QUESTIONS REGARDING THE APPLICATION OF INTERNATIONAL AGREEMENTS IN THE INTERNATIONAL PRIVATE LAW OF THE REPUBLIC OF SERBIA***}

\section{Summary}

In this paper, the authors point out important practical issues arising in the application of international treaties in Private International Law, such as the complex situations that may arise in connection with the entry into force of the treaty, the succession of international treaties, the hierarchy of international treaties, and an analysis of the common rule on the primacy of bilateral treaties. Besides, the need for reviewing existing bilateral treaties Law has been discussed as well, bearing in mind more efficient solutions envisaged in the conventions of the Hague Conference on Private International Law. Finally, the paper also indicates the specific cases where the innovated solutions of the new PIL Act of the Republic of Croatia and the Draft PIL Act of the Republic of Serbia are considerably more favorable than the binding multilateral agreement on determining the content of foreign law.

Keywords: $\quad$ entry into force of international treaty, application of international treaty, hierarchy of international treaties, ratification of international treaties, European Convention on Information on Foreign Law

\section{(c) (1) (8)}

This work is licensed under a Creative Commons

Attribution-NonCommercial 4.0 International License.

* $\quad$ Mirko Živković, PhD, Full Professor, Faculty of Law, University of Niš, Kralja Aleksandra Square 11, 18105 Niš, Republic of Serbia. E-mail address: mirko.zivkovic@yahoo.fr. ORCID: https://orcid.org/0000-0002-5624-9804.

** Sanja Marjanović, PhD, Assistant Professor, Faculty of Law, University of Niš, Kralja Aleksandra Square 11, 18105 Niš, Republic of Serbia. E-mail address: sanjamarjan@yahoo.com. ORCID: https://orcid.org/ 0000-0001-7560-8254.

*** This paper is the result of involvement in the project of the Faculty of Law of the University of Niš "Protection of Human and Minority Rights in the European Legal Space", funded by the Ministry of Education, Science and Technological Development of the Republic of Serbia (evidence number 179046 D). 